\title{
High Preservation Potential Volcaniclastic Sedimentation in the Serravallian Sequence of the Amantea Basin (Coastal Chain, North-Western Calabria)
}

\author{
Cannata Chiara Benedetta ${ }^{1,2, *}$, De Rosa Rosanna ${ }^{1}$, Donato Paola ${ }^{1} \mathbb{D}$, Morrone Consuele ${ }^{1}$ and $^{\text {Muto Francesco }}{ }^{1}$ \\ 1 Department of Biology, Ecology and Earth Sciences, University of Calabria, 87036 Arcavacata di Rende, Italy; \\ rosanna.derosa@unical.it (D.R.R.); paola.donato@unical.it (D.P.); consuele.morrone@unical.it (M.C.); \\ francesco.muto@unical.it (M.F.) \\ 2 E3 Spin-Off, Department of Biology, Ecology and Earth Sciences, University of Calabria, \\ 87036 Arcavacata di Rende, Italy \\ * Correspondence: chiara.cannata@unical.it; Tel.: +39-09-8449-3580
}

\section{check for}

updates

Citation: Chiara Benedetta, C.; Rosanna, D.R.; Paola, D.; Consuele, M.; Francesco, M. High Preservation Potential Volcaniclastic Sedimentation in the Serravallian Sequence of the Amantea Basin (Coastal Chain, North-Western Calabria). Geosciences 2021, 11, 360. https://doi.org/ 10.3390 /geosciences 11090360

Academic Editors: Ian Coulson and Jesus Martinez-Frias

Received: 15 July 2021

Accepted: 20 August 2021

Published: 25 August 2021

Publisher's Note: MDPI stays neutral with regard to jurisdictional claims in published maps and institutional affiliations.

Copyright: (c) 2021 by the authors. Licensee MDPI, Basel, Switzerland. This article is an open access article distributed under the terms and conditions of the Creative Commons Attribution (CC BY) license (https:// creativecommons.org/licenses/by/ $4.0 /)$.

\begin{abstract}
Evidence of volcaniclastic sedimentation occurs in the first depositional sequence of the sedimentary succession of the Amantea Basin. Volcaniclastic deposits are intercalated in the upper part of a sandstone formation and these show a maximum thickness of about $8 \mathrm{~m}$. The Amantea Basin is a Neogene depozone located along the Tyrrhenian margin of Calabria whose onset started during the Upper Serravallian. The source volcano to these materials had to have been located within or near to the marine basin in order to supply it with significant amounts of pyroclastic fragments emplaced by either pyroclastic fall/or flows during one or more explosive eruptions. The marine environment of volcaniclastic flows made up of pyroclastic fragments mixed with minor siliciclastic and carbonate material. The textural and structural features of the deposits and the composition of the volcanic glass fragments indicate an origin from a sub-aerial coeval explosive eruption, with initial sedimentation in a shallow marine environment, mixing with non-volcanic materials, reworking and final re-sedimentation into the basin. The age of the volcaniclastic/sedimentary sequence makes these deposits a marker for the geodynamic evolution of the area, and the lack of such horizons in the other coeval peri-Tyrrhenian basins allows us to consider the Amantea Basin as a confined elongated coastal basin area, whose tectonostratigraphic architecture denotes a structural partitioning of the eastern nascent Tyrrhenian Basin.
\end{abstract}

Keywords: tephra deposit; marine sedimentary basins; paleographic reconstruction

\section{Introduction}

Explosive volcanic activity generates a large volume of fragmented materials, contributing $5-10 \%$ to the total clastic flux on the Earth surface [1]. Pyroclastic deposits are quickly remobilized, reworked and resedimented. Their isochronous deposition over large areas and depositional settings provides a powerful tool for dating and correlating different sedimentary archives. In marine basin analyses, the high preservation potential of volcaniclastic deposits is helpful for the reconstruction of the volcanic history of their source areas. After primary deposition, the unconsolidated pyroclastic deposits can be easily affected by erosion, reworking, and admixture of epiclastic material to form mixed pyroclastic-siliciclastic deposits. The depositional environment and tectonics strongly influence the preservation of volcanic ash. Specifically, volcanic ash deposited during the transgressive phases of sedimentary cycles had a high preservation potential [2]. In any case, they also form important stratigraphic markers for stratigraphic correlations and record information about geodynamic settings and sedimentary processes acting upon these during the transport. Their formation can be initiated by different syn-eruptive events, including primary pyroclastic flows, pyroclastic surges, air fall deposits accompanied by rapid accumulation and remobilization of pyroclasts on the marine slope or syn-eruptive lahars directly discharged 
into the sea. Whatever the triggering mechanism, these materials form a graded sequence that may be linked to a single volcanic event. Secondary volcaniclastic deposits also include immediately post-eruptive erosion and remobilization of primary pyroclastic deposits. By contrast, epiclastic volcaniclastic deposits form by reworking or weathering and erosion of pre-existing pyroclastic deposits and lavas [3]. Moreover, remobilization can occur long after volcanic activity has ceased $[4,5]$. Deep-sea volcaniclastics are often generated by gravitational settings (fallout) of ash produced during large sub-aerial explosive eruptions or by sedimentary gravity flows [6]. This suggests that the majority of deep-sea volcaniclastic deposits are supplied by contemporaneous volcanic activity [7].

This paper presents a detailed field and petrographical study of volcaniclastic deposits outcropping within the Miocene sedimentary succession of the Amantea Basin, located on the western margin of northern Calabria (Figure 1A). The sedimentary infill of late Serravallian to Messinian deposits has been extensively studied [8-17]. It is characterized by lithostratigraphic units grouped in depositional units, each one bounded by stratigraphic discontinuities [17] and partly corresponding to the depositional sequences described by other authors [18-20]. In particular, in the Late Serraviallian-Messinian interval, three depositional sequences bounded by unconformities have been recognized $[18,19]$.

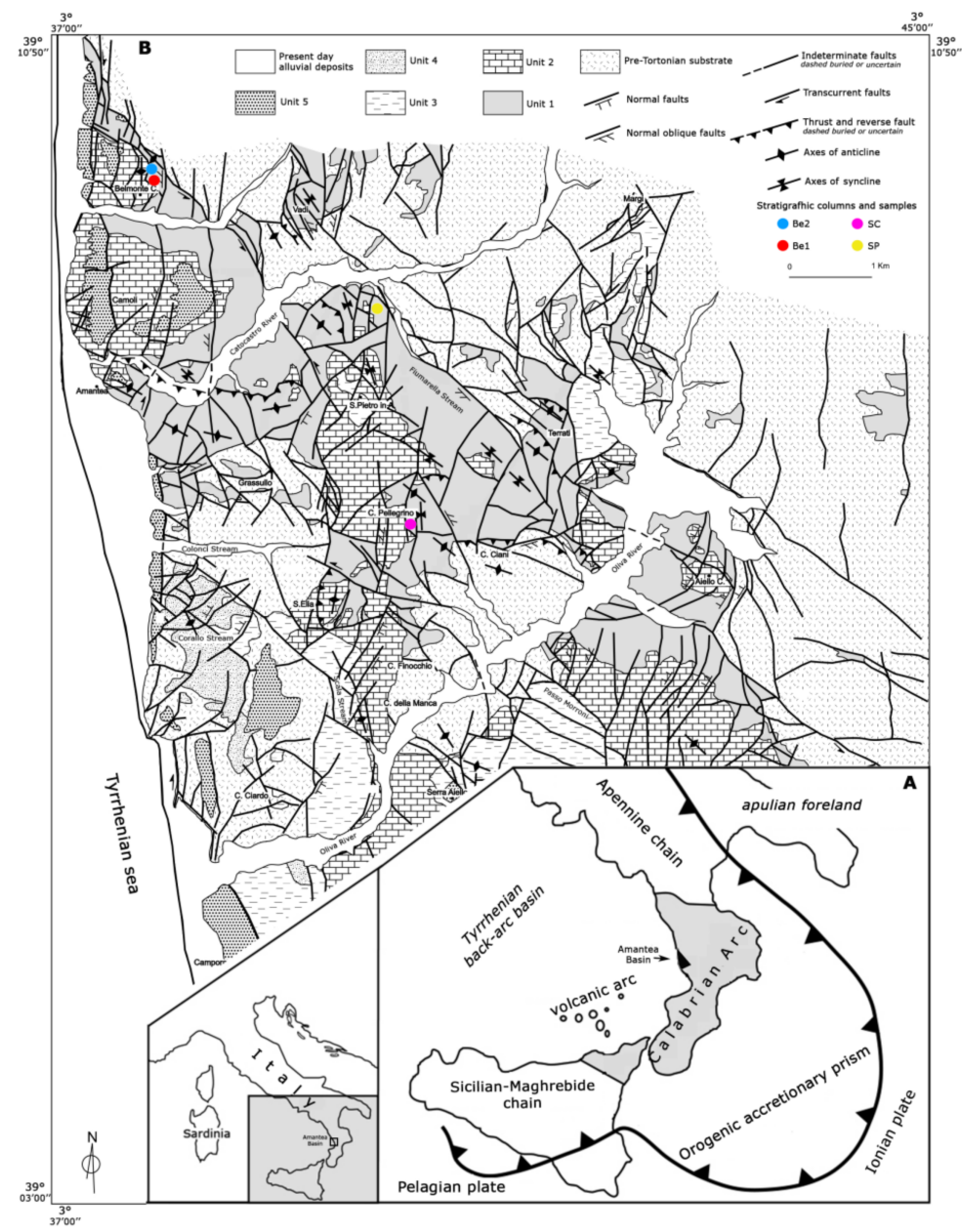

Figure 1. (A) Location of the Amantea Basin within the southern Tyrrhenian-Calabrian Arc system and Italy (inset). (B) Geological map of the central-northern portion of the Amantea Basin in which the stratigraphic columns and relative sample sites of Figure 2B are indicated (Be-Belmonte; $\mathrm{SP}-$ San Pietro; SC-Santa Caterina). The depositional units refer to in [17]. Unit 1 corresponds to the depositional sequence DS1 of Figure 2A. Units 2 and 3 correspond to the depositional sequence DS2 of Figure 2A. Unit 4 corresponds to the sequence DS3 of Figure 2A. For lithological units see Figure 2A. Modified after [17]. 
A

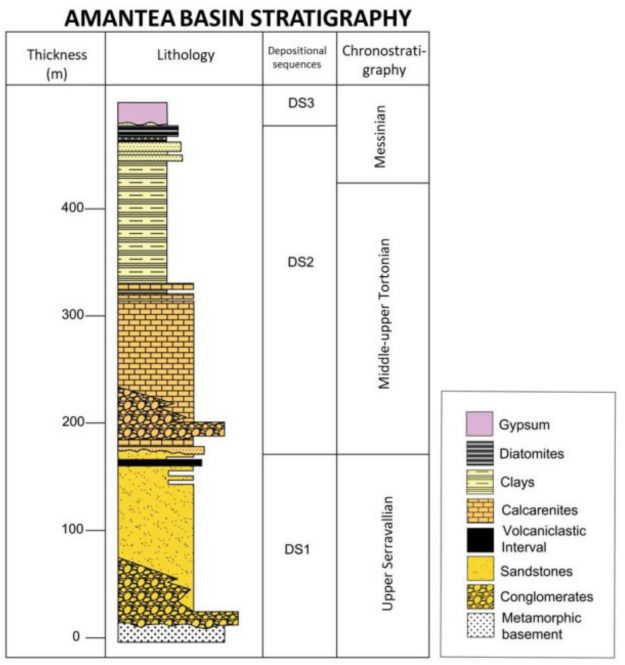

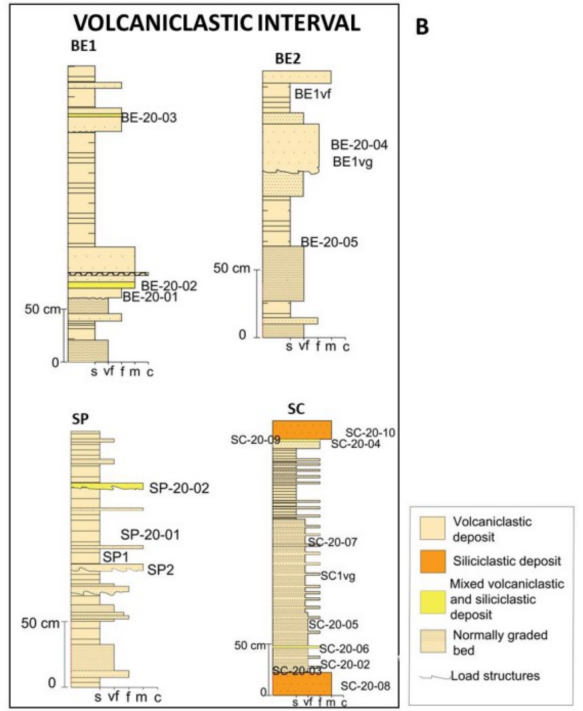

Figure 2. (A) Stratigraphic columns of the Amantea Basin, modified after [18] and (B) stratigraphic columns of the volcaniclastic interval.

The volcaniclastic deposits of this study are hosted at the top of the first depositional unit (Figure 1B), within the sandstone formation (Figure 2A) [18], and crop out with a thickness ranging from 2 to $8 \mathrm{~m}$. Thus, the occurrence of secondary volcaniclastic sedimentation in the Serravallian sequence of the Amantea Basin could be considered a lithostratigraphic marker for the geodynamic evolution of the area, since the lack of such an horizon in the other coeval peri-Tyrrhenian basins allows us to consider the Amantea Basin as a confined elongated coastal basin area.

Thus far, the lack of documented proximal deposits has not permitted correlation. Future work on trace elements and isotope glass geochemistry will be necessary to develop a more plausible hypothesis about the magmatic source of the deposit.

\section{Geological Background}

The Amantea Basin is located at the southeastern margin of the Tyrrhenian Basin (Figure 1) and exposed at the western coast of Calabria (south of Italy). The basin substrate is formed by composite terrane belonging to the Calabrian Arc (CA). The CA is interpreted as a present-day arcuate-shaped orocline or as the result of the distortion of an originally straight segment of lithosphere, related to the opening of the Tyrrhenian Sea [21]. The basin started to develop at the limit of the Upper Serravallian-Tortonian stages at the opening of the Tyrrhenian Basin. Progressive development of downthrow block faulting formed coalescence fault-bounded coastal depressions infilled by transgressive succession, showing a deepening-upward trend passing from continental to shallow and relatively deep marine deposits [19]. Its origin is linked to extensional deformations of the backarc area at the beginning of Tyrrhenian rifting ([17,18], and refs. therein). In particular, the Amantea Basin formed in an extensional tectonic regime, with a constant $\mathrm{N} 110^{\circ}-120^{\circ}$ orientated stretching direction $[11,14,15,18,22]$. The basin represents the conjugate margin of the eastern Sardinia margin [21]. The Amantea Basin was rifted during the Serravallianearly Tortonian toward E-W, and later drifted southeastward and rotated clockwise at its present-day location [18]. The sedimentary succession filling the Amantea basin lies on the crystalline rocks of Calabride Complex and ophiolites of Liguride Complex of Calabrian Arc (Figure 1) ([17] and refs. therein), whose origin is linked to either the European plate margin [23-28] or African plate margin [29-31]. Both Complexes overthrust the Mesozoic carbonates of the Adriatic-African plate margin with the subsequent migration toward the southeast, following the subduction of oceanic lithosphere. The overthrust, combined with the progressive migration of the Calabrian Arc towards the S-E, was associated with the opening of the Tyrrhenian Basin that initiated in the from Middle Miocene [24,32-34]. 
Thick and continuous successions of Miocene basins, like the Amantea one, occur in several outcrops along the Tyrrhenian margin of Calabria (Paola and Belvedere Marittimo basins, [35]). Since the mid-Miocene, the Calabrian Arc has migrated toward the S-E in response to the subduction of the Ionian oceanic lithosphere along the W-dipping Benioff zone ([35] and refs. therein). The migration toward SE followed three main stages: the first one is the result of the subduction process linked to the opening of the Ligurian-Provencal basin, forming an accretionary wedge and the rotation of the Sardinian-Calabrian block. The first stage is also characterized by the obduction of the Ligurian wedge [36] and the Oligo-Miocene extensional phenomena responsible for the exhumation of high-grade metamorphic rocks [17]. The second stage was caused by the overlapping crystalline rocks of the basement and accretionary wedge on the Adriatic-African margin over E-W, WNW-ESE regional faults of Langhian-Tortonian age [37-42]. The third stage started following the Tyrrhenian rifting during the Tortonian [38], as testified by compressive NW-SE lineaments coeval to the extensional events [43]. A continuous WNW-ESE-orientated extension direction was recognized [18]. The Amantea Basin extensional tectonic activity represents an almost unique feature in Italy. Indeed, while in the northern and southern Apennines, the extensional tectonics progressively migrated from $\mathrm{W}$ to $\mathrm{E}$, following the foreland migration of the Apennines orogenic deformation [44-48] and late Miocene extensional basins does not show significant present-day normal faulting, and the Tyrrhenian margin of northern Calabria has been clearly deformed by extensional tectonics from the Serravallian to the Pleistocene. This is confirmed by the presence of uplifted marine terraces and erosional surfaces, the normal faults cutting the Pleistocene palaeosoils, and by the historical earthquakes in the region $[49,50]$.

\section{Methods}

\subsection{Field Observation and Sampling}

To obtain a representative suite of samples from the Amantea Basin (e.g., [51]), the volcaniclastic deposits were observed and sampled in three study areas along 4 stratigraphic columns (Figure 2B).

From the coast to the hinterland, across an NW-SE direction, the investigated horizons weresampled in Belmonte Calabro (BE), S. Pietro in Amantea (SP) and S. Caterina (SC) villages. In Belmonte Calabro the volcaniclastic layer outcrops along the road SP44: we sampled both coarse and fine volcaniclastics in correspondence of two sites (Site 1: 593185.00 E; Site 2: 4335262.00 N-593017.00 E; 4335318.00 N). Here we collected the following samples: BE1vg, BE1vf, BE-20-01, BE-20-02, BE-20-03, BE-20-04, BE-20-05 (Figure 2B). The third sampling site is situated close to the S. Pietro in Amantea village (596104.00 E; 4333507.00 N). Samples are named: SP1, SP2, SP-20-01, SP-20-02; while the fourth and last, with two sampling sites, is located near $\mathrm{S}$. Caterina village, where the volcaniclastic succession reaches the maximum thickness and the best exposition. The collected samples are: SC1vg, SC1vf, SC-20-01, SC-20-02, SC-20-03, SC-20-04, SC-20-05, SC-20-06, SC-20-07, SC-20-08, SC-20-09, SC-20-10. The description of samples is reported below in Section 4.

\subsection{Analytical Methods}

\subsubsection{Petrography}

The petrography of the samples was studied by sample thin sections under both the polarizing microscope and the scanning electron microscope (SEM). We selected 14 unaltered samples for thin section analysis under the polarizing microscope. Medium to fine sandstones were analyzed by the Gazzi-Dickinson method of petrographic analysis (e.g., [52,53]) to minimize the dependence of arenite composition on grain-size or changes in rock fragments microfabric (e.g., [20]). According to the Gazzi-Dickinson method, quartz, feldspars, and phyllosilicates contained in coarse or "phaneritic" rock fragments are considered as a part of the monocrystalline framework to reduce the dependence of modal composition of arenites and sands on grain size [52-57]. Detailed petrographic classes used for modal point-counting (Appendix A) gave us the possibility to recalculate 
the phaneritic fragments contained in a sand (stone). The overall framework and interstitial composition of the sampled sandstones and the assigned petrographic categories are shown in Appendix A, Tables 1 and 2. Fourteen samples were selected according to their grain-size (sand-size). Five hundred points per thin section at a spacing of $0.5 \mathrm{~mm}$ were counted except for BE1VF. Only one hundred points were analyzed for this sample because its grain size ranges from silt/clay to very fine sand. Framework grains and interstitial components categories and the recalculated parameters are those of $[55,58-60]$ (Appendix A; Tables 1 and 2). The "undetermined grain" class includes grains altered beyond recognition (Appendix A; Table 1). In addition to classical Q + C:GRF + GneissRF: other + C [58], LmLvLs (e.g., [59]), we used less traditional diagrams (e.g., Lv:M:S) (Figures 3 and 4 ), to consider the information from the volcaniclastic supply combined with the non-volcanic components in the studied arenites. Specifically, the diagram shown in Figure 4B may be useful particularly for unravelling sand-size sediments provenance in geodynamic settings where explosive arc magmatism produces pyroclastic units as potential source rocks (e.g., [61,62]).

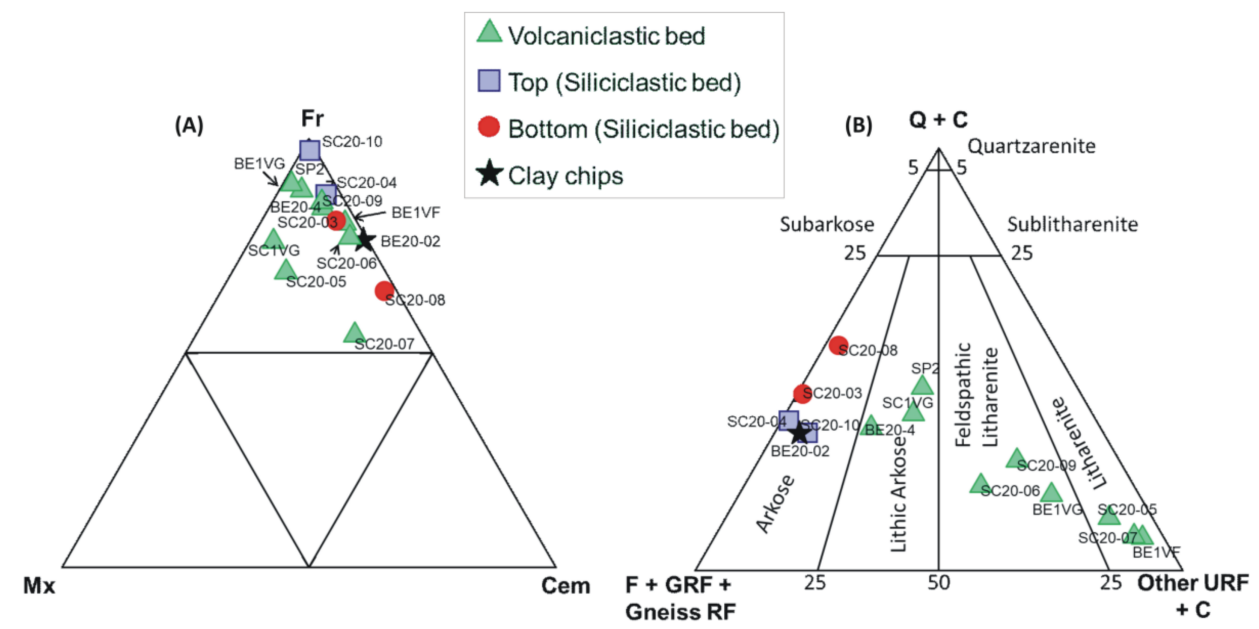

Figure 3. (A) Relative proportions of Framework: Matrix:Cement. Framework (Fr): total detrital grains: Matrix (Mx): Siliciclastic + Carbonate matrix; Cement (Cem): Carbonate cement + Oxid-Fe cement. See Table 1 for the abbreviations. (B) Traditional sandstone classifications after [59].

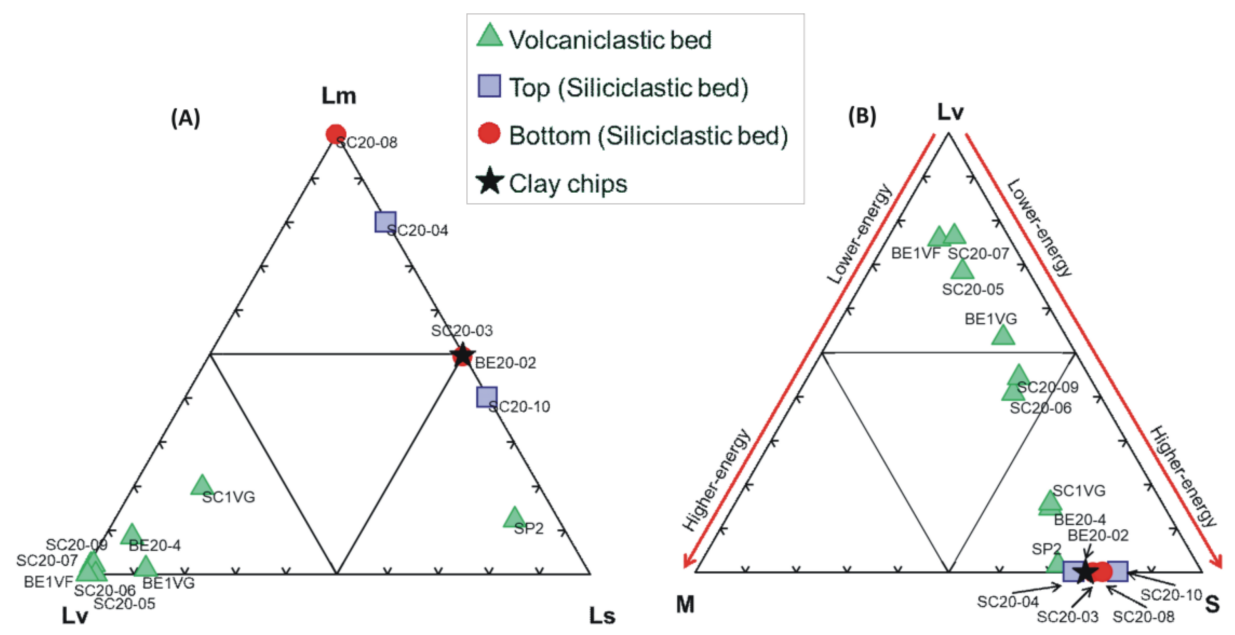

Figure 4. (A) Ternary plot of the relative proportions of Lm:Lv:Ls. Lm: metamorphic lithics; Lv: volcanic lithics; Ls: sedimentary lithics (modified from [60]). (B) Relative proportions of Lv:M:S (e.g., [61]). Lv: All volcanic lithic textures (Lvl + ALvl + Algl + Lvf + Pm + Apm + Shard); M: mafic single crystal grains (pyroxene + amphibole + garnet + biotite + opaques); S: sialic single crystal grains (plagioclase $+\mathrm{K}$-feldspar + monocrystalline and polycrystalline quartz without tectonic fabric). 
Table 1. Key to counted parameters (modified from [61-64]).

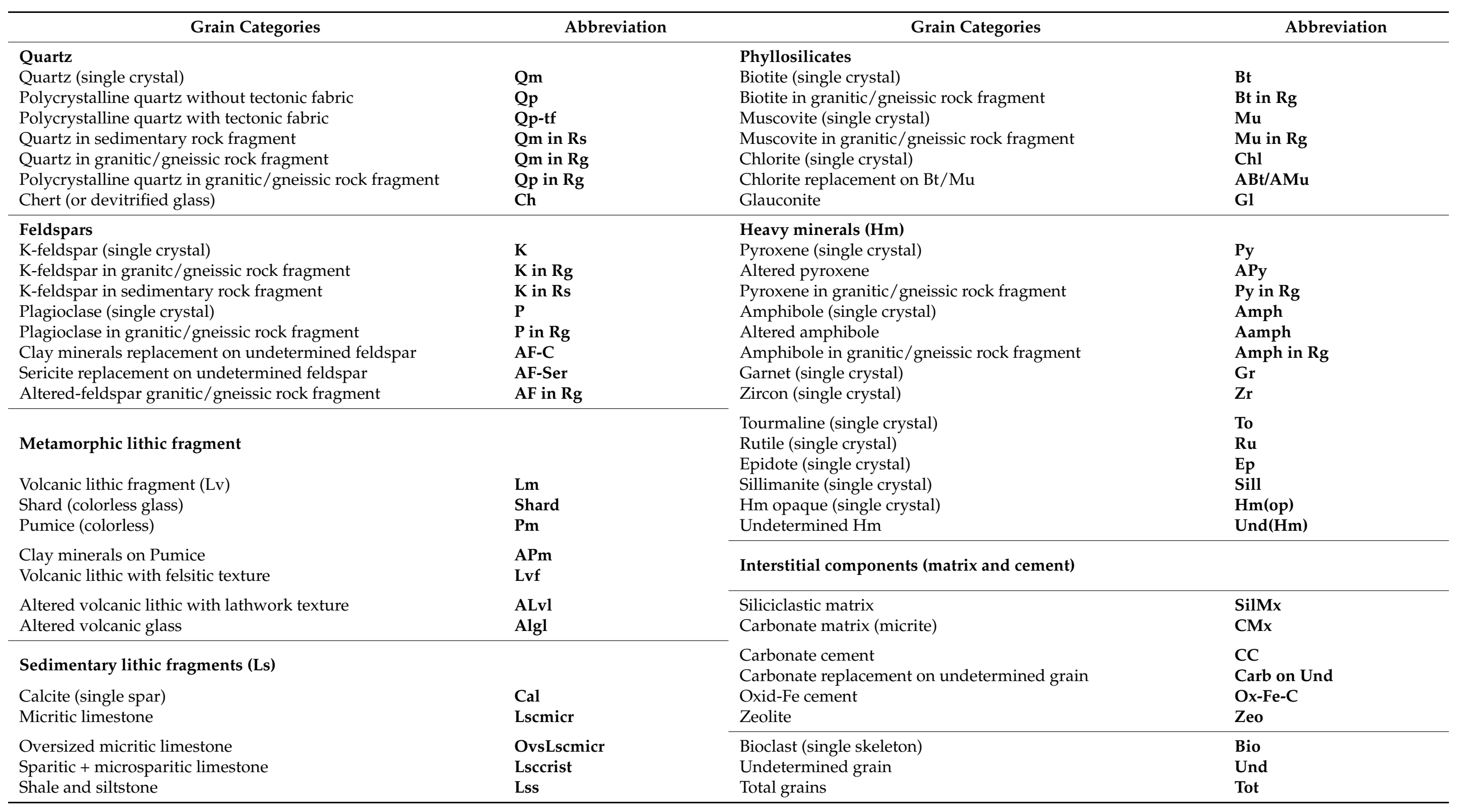




\subsubsection{Imaging and Chemical Analyses}

Imaging of volcanic fragments was performed using a Field-Emission Scanning Electron Microscope FEI QUANTA 200 at CM2 Laboratory (Microscopy and Microanalysis Center, University of Calabria). Detector constants and work conditions were as follows: tilt angle $0^{\circ}$, voltage $20 \mathrm{kV}$, beam diameter of $4 \mu \mathrm{m}$ and a beam current of $10 \mathrm{nA}$; working distance $12 \mathrm{~mm}$.

Major element composition of volcanic fragments (glass and crystals in samples: BE1VG, BE1VG, SC1VG, BE-20-05, SC-20-05) was obtained by X-ray wavelength dispersive spectroscopy (WDS) coupled to an Electron Probe Micro Analyzer JEOL-JXA 8230 of CM2 Laboratory. The instrument is equipped with a W/LaB6 source and with 5 WDS Spectrometers with LDE, TAP, PETJ and LiF crystals, and a Si/Li crystal detector model EDAX-GENESIS 4000. Detector constants and work conditions for major element determination on crystals were as follows: tilt angle $0^{\circ}$, voltage $15 \mathrm{kV}$, beam diameter of $2 \mu \mathrm{m}$ and a beam current of $10 \mathrm{nA}$; while for glass analyses tilt angle $0^{\circ}$, voltage $15 \mathrm{kV}$, a $2 \mu \mathrm{m}$ defocused beam and a beam current of $6 \mathrm{nA}$. Acquisition times for crystal analyses were $20 \mathrm{~s}$ for the elements $\mathrm{Fe}, \mathrm{Cl}, \mathrm{Mn}, \mathrm{Ti}, \mathrm{Mg}$ and $\mathrm{P}$ and $10 \mathrm{~s}$ for $\mathrm{F}, \mathrm{Si}, \mathrm{Al}, \mathrm{K}, \mathrm{Ca}$ and $\mathrm{Na}$; while for glass analyses: $10 \mathrm{~s}$ for $\mathrm{Na}$ and $30 \mathrm{~s}$ for the other elements. Analytical precision is $0.5 \%$ for concentrations higher than $15 \mathrm{wt} . \% 1 \%$ for about $5 \mathrm{wt} . \%, 5 \%$ for abundances of $1 \mathrm{wt} . \%$ and less than $20 \%$ for concentrations near the detection limit, never below $1000 \mathrm{ppm}$.

\section{Results}

\subsection{Description of the Volcaniclastic Deposits}

The volcaniclastic deposits outcrop within the first depositional sequence of the Upper Serravallian sedimentary succession of the Amantea Basin. The most suitable successions outcrop in Belmonte Calabro (BE), S. Pietro in Amantea (SP) and S. Caterina (SC), with a thickness ranging from 2 to $8 \mathrm{~m}$ (Figure 2A). The literature reports that the volcaniclastic deposits lie at the top of an arenitic interval belonging to deltaic sandstones facies of the first depositional unit [16] and are covered by the levels of arenites. Thus, from a compositional point of view, the first depositional unit of the succession of the Amantea Basin can be divided into three different intervals:

$>$ Bottom arenitic interval
$>\quad$ Volcaniclastic interval
$>\quad$ Top arenitic interval

The volcaniclastic interval comprises several beds inside which both volcanic and sedimentary material can be found. In general, the observed thickness of the interval ranges from 2 to $8 \mathrm{~m}$ and is made by normally graded coarse sand to silt beds with colors ranging from light brownish to dark grey, yellow or deep yellow. The coarser beds are massive and composed of both volcanic and non-volcanic fragments in different proportions. At the same time, the thinner is laminated and mainly made of volcanic glass shards and pumices. From the bottom to the top and an overall grain size decrease and thickness increased within each bed are observed.

The first studied outcrop in Belmonte Calabro (BE) (Site 1) is about $8 \mathrm{~m}$ thick. Here there is no evidence of outcropping fan delta siliciclastic arenites (bottom and top arenites). The first layer of the volcaniclastic interval consists of massive and coarse-grained whitish beds (sample BE-20-01). On the top lies a chaotic deposit composed of fine and massive volcaniclastic silt with interbedded coarser layers of predominant siliciclastic composition of centimetric to decimetric thickness (Figure 5A) (BE-20-02). Sometimes these well-preserved coarse-grained intercalations within the volcaniclastic silty beds are mm-thick and often oxidized (BE-20-03) (Figure 5B). In the second outcrop of BE (Site 2) the upper-middle portion of the interval and the rhythmic alternation of coarser and fine-grained beds of predominant volcaniclastic composition are well preserved (Figure 5C). Again, the volcaniclastic interval begins with a coarse-grained volcaniclastic bed (BE-20-04, BE1VG) overlain by fine-grained and laminated volcaniclastic beds (BE-20-05, BE1VF). The volcaniclastic interval outcropping in S. Pietro in Amantea (SP) exhibit a still finer grain size and is 
represented by fine-laminated beds in respect to those of BE. From BE to SP, an overall decrement of thickness and grain size of the volcaniclastic beds is observed. Here we collected three samples of the volcaniclastic deposit (SP-20-01, SP1, SP2) and 1 sample of mixed volcaniclastic and siliciclastic deposit (SP-20-02).

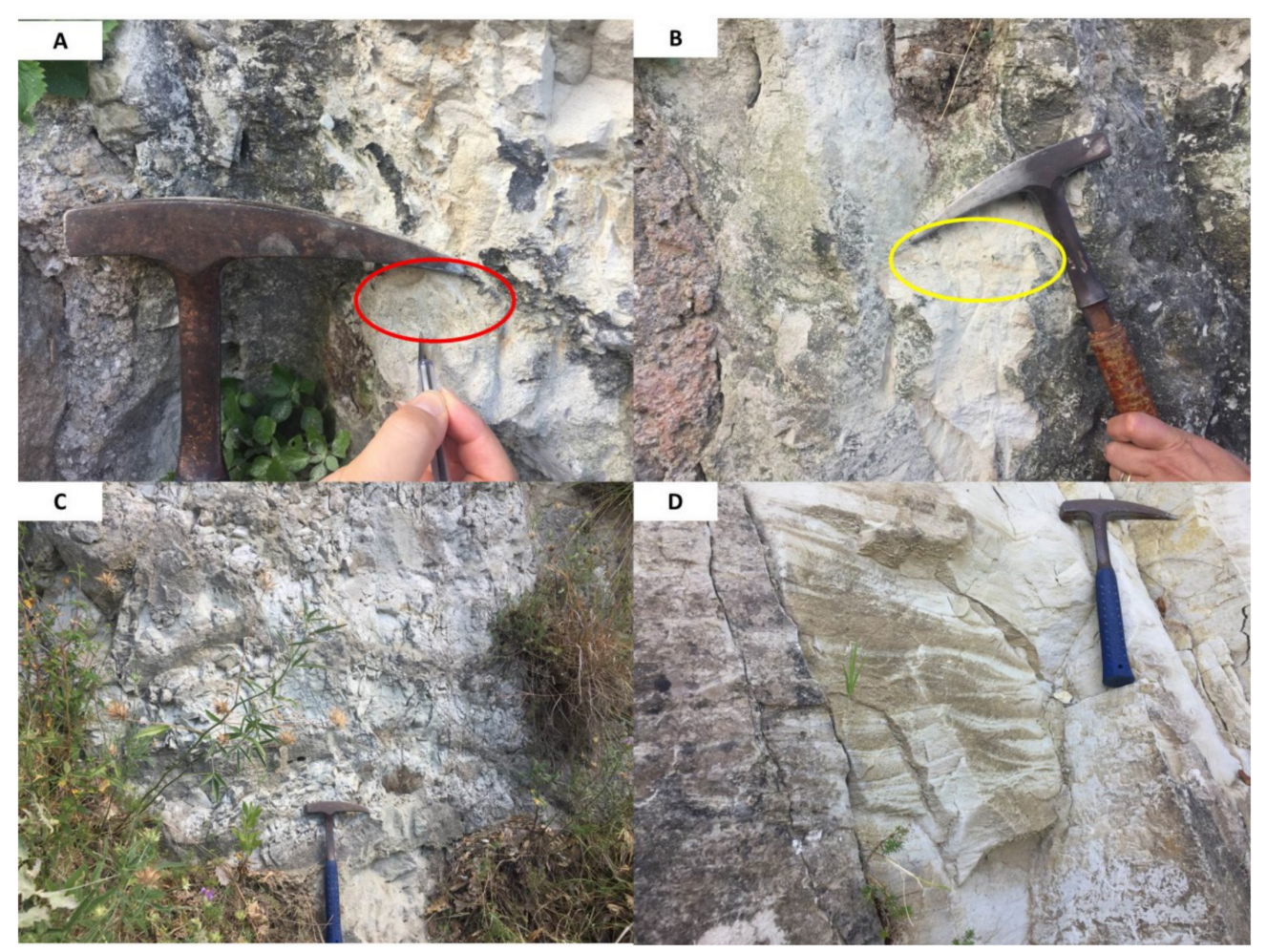

Figure 5. Volcaniclastic interval on the field: (A) red circle: interbedded coarser layers of predominant siliciclastic composition (BE-20-02); (B) yellow circle: oxidized interbedded coarser layers of predominant siliciclastic composition (BE-20-03); (C) rhythmic alternating coarse and fine beds of the volcaniclastic interval in Belmonte outcrops; (D) S. Caterina outcrop (SC-20-05, SC-20-07).

In the S. Caterina site, the volcaniclastic interval is interbedded, both at the base (SC-20-08) and the top within the lower and upper siliciclastic arenites of the Amantea basin (SC-20-10). The first observed outcrop (not reported in Figure 2) displays the lower siliciclastic arenitic beds (SC-20-01) at the base overlain by the volcaniclastic interval made up of very fine volcaniclastic beds (SC-20-02). The transition from the lower siliciclastic arenites to the volcaniclastic interval is gradual. In particular, a mixed volcanic and siliciclastic bed occurs at the contact between the two lithologies (SC-20-03). The arenitic beds of the upper siliciclastic interval ends the first depositional unit of the Amantea Basin (SC-20-04). The second outcrop of SC shows the best exposure of the volcaniclastic interval, with a thickness of about $7 \mathrm{~m}$. The volcaniclastic beds are very fine-grained and well laminated (SC-20-05, SC-20-07) (Figure 5D). At $2.5 \mathrm{~m}$ from the base, we observed a series of coarse-grained beds of predominant siliciclastic composition interbedded within the fine-grained volcaniclastic beds with an undulated lamination at the top (SC-20-06) and a gradual contact (SC-20-09). The grain-size gradation observed from the base to the top of the volcaniclastic interval, the predominance toward the top of thicker fine-grained laminated beds, the clast composition of the beds, with a gradual increase in the abundance of the volcaniclastic component in the finer grain-size in respect to the coarse-grained beds characterized by mixed volcanic and non-volcanic detritus, suggest that the delta system of the first sequence of the Amantea basin were fed by a sudden volcanic supply by subaerial volcanic explosive eruptions, with rapid mixing of volcanic and non-volcanic sediment, transfer from the source to basin and final sedimentation by gravity flows. The massive coarse-grained volcaniclastic beds could have been deposited from the rapid 
settling of inertial-dominated turbulent sediment-laden currents [65]. The normal grading and the predominance of tractional structures in the upper beds of the volcaniclastic interval suggest the incremental deposition from a waning sediment-laden subaqueous flow [65]. The upper laminated beds are interpreted as deposition by traction-plus-fallout sedimentation from a more upper diluted plume [66]. The massive fine-grained beds may be attributed to the settlement of silt from a turbulent suspension during the waning flow stages.

\subsection{Petrography}

Most of the analyzed samples contain appreciable amounts of detrital framework grains (Figure 3A). In three samples (Santa Caterina village: SC1VG, SC20-05, SC20-07), siliciclastic matrix exceeds $15 \%$ of the total components; these matrix-rich arenites can be therefore termed as greywackes instead of arenites if Dott's classification is used (e.g., [67]).

\subsubsection{Framework Grains}

Aphanitic lithics (Other URF + C), feldspar (F + GRF + Gneiss RF) and quartz $(\mathrm{Q}+\mathrm{C})$, are the principal framework components of the Amantea arenites (Table 2; Figure 3B). Quartz occurs mainly as sub-angular to sub-rounded monocrystalline grains (Figures 6B and 7A,D); polycrystalline quartz includes microcrystalline grains without a clear tectonic fabric and minor grains with tectonic fabric.
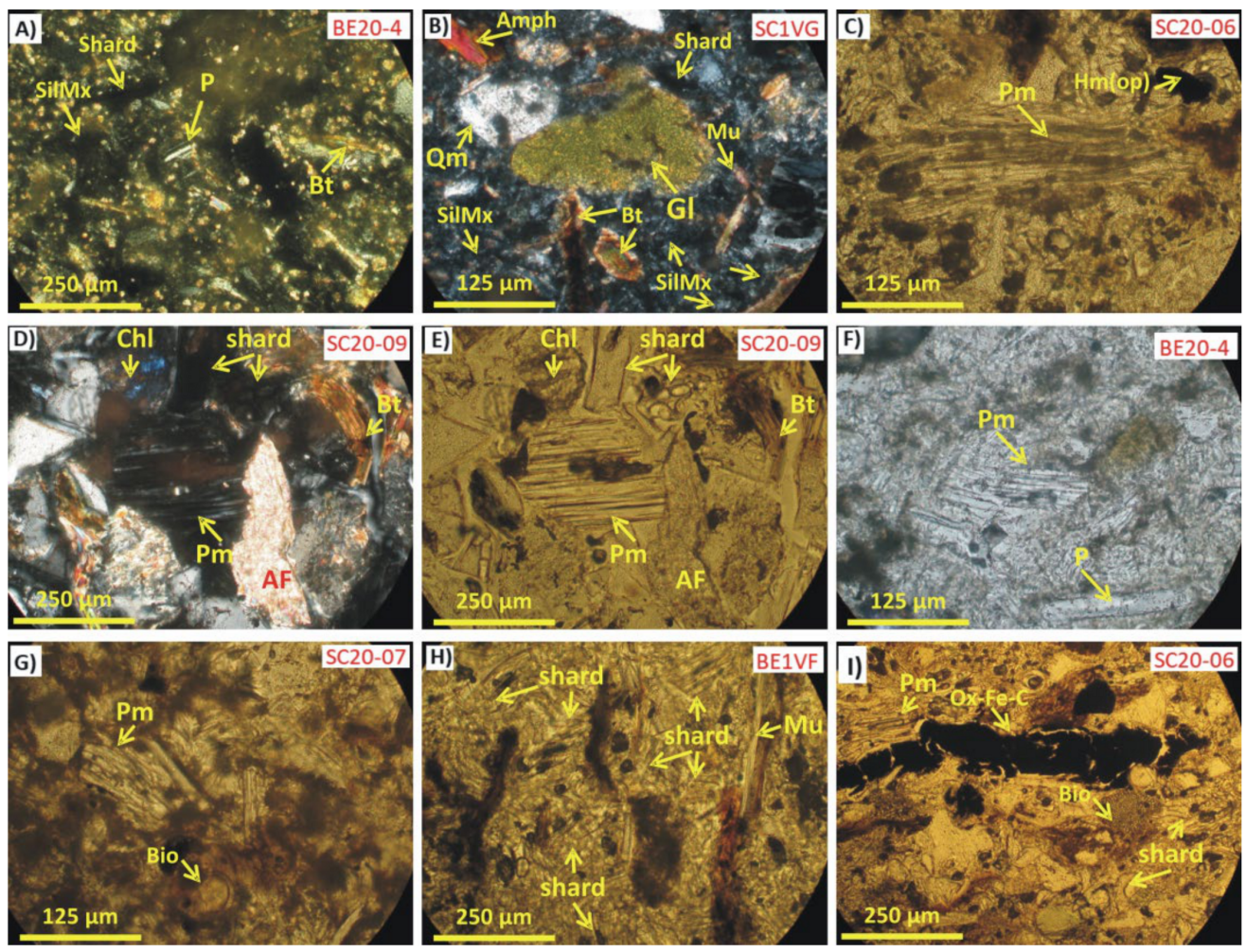

Figure 6. Photomicrographs from petrographic thin sections illustrating diagnostic grains of Santa Caterina (SC) and Belmonte (BE) outcrops. (A) Volcaniclastic bed showing silt-sized plagioclase (P) and dominant shards. SilMx: siliciclastic matrix (mainly includes silt to clay-sized shards and pumice). Bt: biotite flake. (B) Glauconite (Gl) in a volcaniclastic interval. Amph: amphibole. Bt: biotite. Mu: muscovite. SilMx siliciclastic matrix (mainly shards, pumice and phyllosilicates). Qm: monocrystalline quartz. (C-I) Volcanic grains (Lv) such as pumice (Pm) and shards with different and diagnostic shapes. P: plagioclase lath. AF: undetermined altered feldspar. Bt: Biotite. Mu: muscovite. Chl: chlorite. $\mathrm{Hm}(\mathrm{op})$ : opaque heavy minerals. OX-Fe-C: Oxid-Fe cement. Bio: bioclast (single skeleton). (A,B,D) are crossed-nicols photomicrographs; (C,E-I) are plane-polarized-light photomicrographs. 
Table 2. Recalculated parameters.

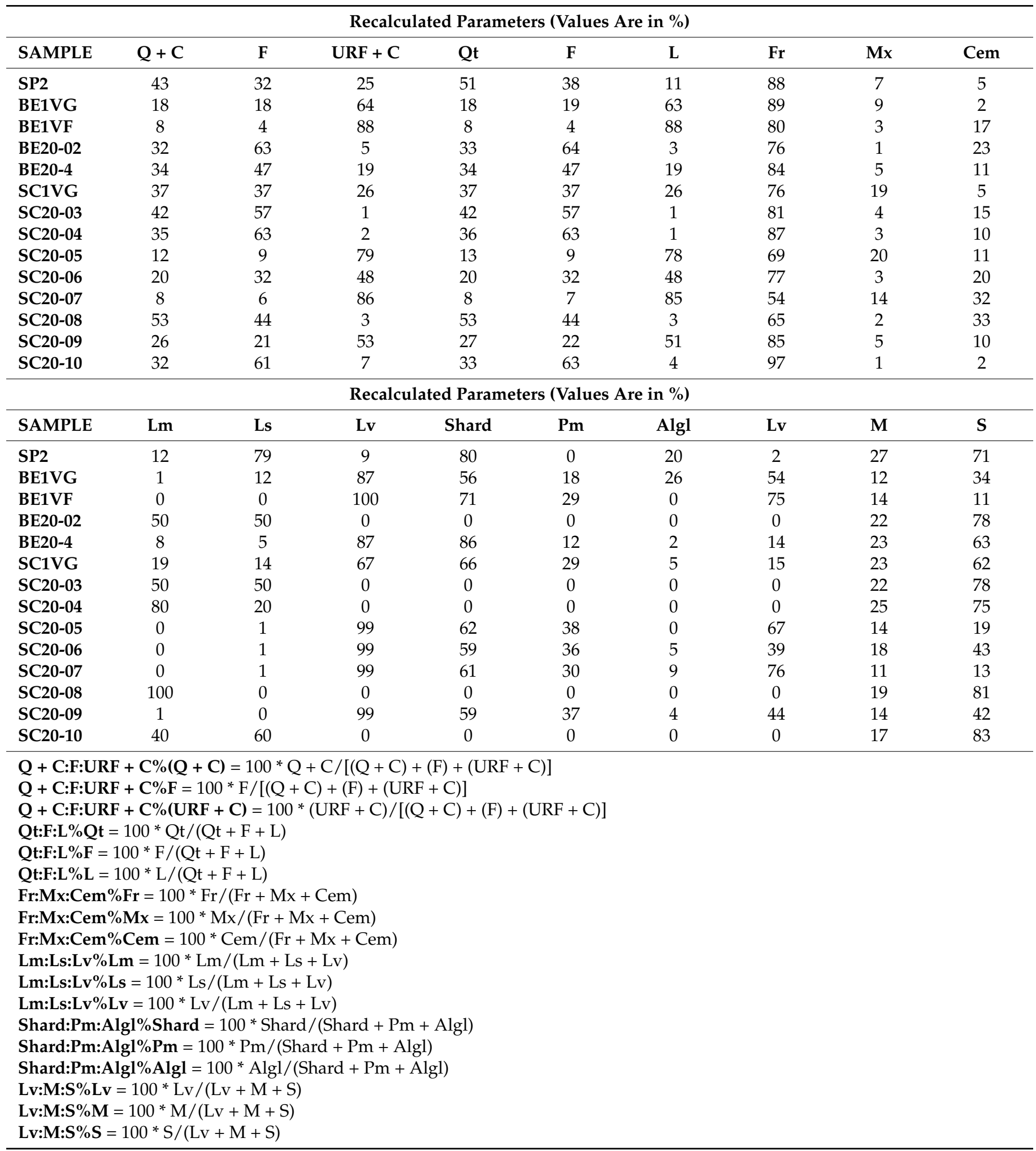


Table 2. Cont.

Keys for Recalculated Parameters

$\mathbf{Q}+\mathbf{C}=\mathrm{Qm}+\mathrm{Qp}+$ Chert $(\mathrm{Ch})$

$\mathbf{F}=$ total feldspars + granitic + gneissic rock fragment $(\mathrm{Rg})$

$\mathrm{URF}+\mathrm{C}=$ other unstable rock fragments $(\mathrm{Lm}+\mathrm{Lv})+\mathrm{C}($ Lscmicr + Lsccrist $)$

$\mathrm{Qt}=$ total quartz $(\mathrm{Qm}+\mathrm{Qp})$ including chert $(\mathrm{Ch})$

$\mathbf{L}=$ total lithic grains $(\mathrm{Lm}+\mathrm{Lv}+\mathrm{Ls})$

Fr $=$ framework (all grains)

$\mathbf{M x}=\mathrm{SilMx}+\mathrm{CMx}$

$\mathrm{Cem}=\mathrm{Ox}-\mathrm{Fe}-\mathrm{C}+\mathrm{CC}+$ CarbonUnd

$\mathbf{L v}=$ All volcanic lithic textures $(\mathrm{Lvl}+\mathrm{Lvmi}+\mathrm{Lvv}+\mathrm{Lvf}+$ pumice grains $)$

$\mathbf{M}=$ mafic single crystal grains ((Py $+\mathrm{Amph}+\mathrm{Gr}+\mathrm{Bt}+\mathrm{Hm}(\mathrm{Op}))$

$\mathbf{S}=$ sialic single crystal grains $(\mathrm{P}+\mathrm{K}+\mathrm{Qm}+\mathrm{Qp})$

Rare cryptocrystalline quartzose grains (chert) were also included in the quartz category. Much attention, during the point-counting, was given to reconstructing the original feldspar grains compositions and optical characters such as zoning and twinning. Feldspars (K-feldspar, microcline, and plagioclase) are characterized by a wide range of sizes, shapes and alteration processes: some grains are virtually fresh, whereas clay minerals, calcite, sericite and Fe-oxides have largely replaced others, (Figures 6C,D and 7B-D). Silt-sized twinned laths of plagioclase set in a fine-grained siliciclastic matrix have also been reported (Figure 6A,F). Aphanitic lithics (L) are dominantly volcanic, sedimentary and metamorphic (Appendix A; Table 2; Figure 4A). Various types of felsitic volcanic grains (Lv of [55]) were recognized and they were distinguished as glass shards, pumice and glass grains that, although altered, retained their original structure (Figures 6 and 7C). Pumice particles show mostly stretched vesicles that, in some cases, are filled up by clay minerals; survived glass shards have a typical " $Y$ " shape and are slightly curved, testifying their magmatic origin (e.g., [68]) (Figures 6, 7C and 8A) Sedimentary lithics are both carbonate and siliciclastic (Appendix A; Table 2; Figure 7A,B,D,E). Carbonate sedimentary lithics, including single detrital spars of calcite, are mainly extrabasinal limestones (e.g., CE of [56]) with micritic, sparitic and microsparitic textures. In contrast, a minor proportion of oversized micritic limeclasts are attributed to intrabasinal origin (CI of [56]). Siliciclastic sedimentary lithics are shales and siltstones, these latter showing a clastic texture of silty quartz grains with micritic matrix. Aphanitic metamorphic lithic fragments (Lm) include only phyllites and fine-grained schists (Figure 7A). Phyllites and fine-grained schists are fragments of quartzmicas tectonites exhibiting foliated fabric (e.g., lepidoblastic texture), undulose extinction of quartz and parallel to the subparallel alignment of micas, suggesting a medium to high metamorphic grade of the source rocks (e.g., [69]). Coarse-grained fragments with phaneritic texture are plutonic and gneissic rocks $(\mathrm{Rg})$ and are composed mainly by a characteristic paragenesis of quartz + plagioclase + biotite (Figure 7B). The heavy minerals include nonopaque and opaque species (Appendix A). Many mafic non-opaque minerals show little or no evidence of corrosion or dissolution morphologies (e.g., [70]). Amphiboles, pyroxenes and opaques are the most abundant heavy minerals species, followed by garnet, zircon, tourmaline, rutile, epidote and sillimanite (Figure 7A-C,E,F). Pyroxene and amphibole occur mainly as single grains and as accessory minerals contained in very few phaneritic granitic/gneissic rock fragments. The other detrital heavy minerals are monocrystalline grains that, in some arenite samples, developed delicate mineral laminae concentrations. Detrital micas are mainly biotite and muscovite with small amounts of chlorite, and occur in monocrystalline flakes or plates, or in very few phaneritic granitic/gneissic rock fragments (Appendix A; Figures 6A-D,H and 7A,B,F). The platy shapes are oriented parallel to bedding. Sometimes biotite and muscovite grains show a chlorite replacement (Appendix A; Figure 6C,D). Glauconite pellets occur in trace amounts (Appendix A; Figure 6B). 

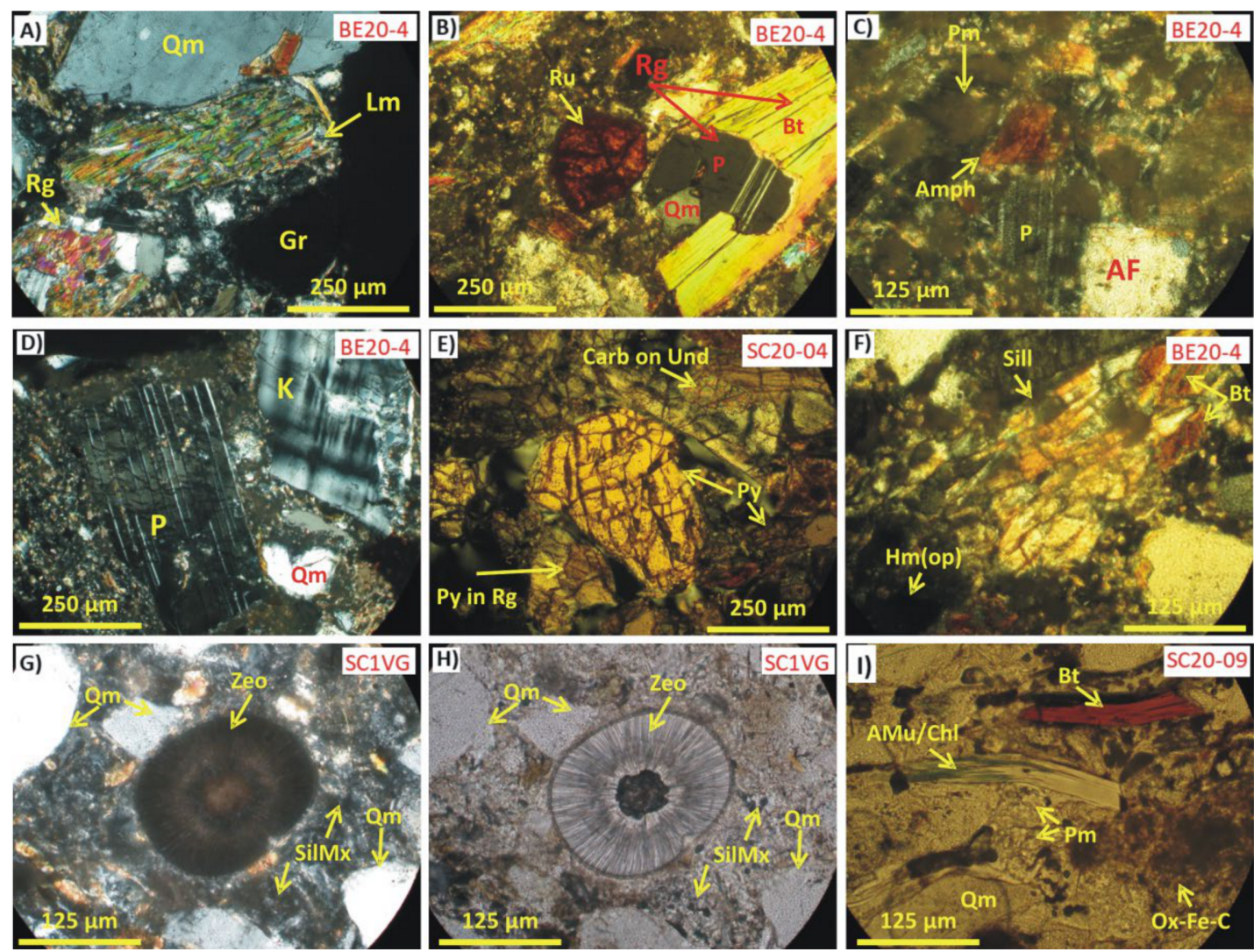

Figure 7. Photomicrographs from petrographic thin sections illustrating diagnostic grains of Santa Caterina (SC) and Belmonte (BE) outcrops. (A) Metamorphic fragments ( $\mathrm{Lm}$ ) with lepidoblastic texture. Rg: phaneritic granitic/gneissic rock fragment. Monocrystalline quartz $(\mathrm{Qm})$ and garnet $(\mathrm{Gr})$. (B) Coarse-grained granitic/gneissic rock fragments (Rg) including biotite $(\mathrm{Bt})$, plagioclase and quartz $(\mathrm{Qm})$. Ru: sub-rounded single crystal of rutile. (C) Cineritic layer with pumice grain $(\mathrm{Pm})$, monocrystalline plagioclase $(\mathrm{P})$ and brown amphibole (Amph). AF: Sericite replacement on undetermined feldspar. (D) P: single crystal of plagioclase supplied by granitic/gneissic source rocks. K: single crystal of K-feldspar (microcline). Qm: monocrystalline quartz. (E) Abundant monomineralic grains of pyroxene (Py) and few pyroxene in granitic/gneissic rock fragments (Py in in Rg). Carb on und: carbonate replacement on undetermined grain. (F) Sill: Sillimanite (fibrolite variety). $\mathrm{Hm}(\mathrm{op})$ : opaque heavy mineral. Bt: Biotite. (G,H) Fan-shaped fibrous zeolite (Zeo). SilMx: siliciclastic matrix. Qm: monocrystalline quartz. (I) Biotite (Bt) and muscovite (Mu) flakes. AMu/Chl: chlorite replacement on muscovite. Qm: monocrystalline quartz. OX-Fe-C: Oxid-Fe cement. Pm: pumice. (A-G) are crossed-nicols photomicrographs; (H,I) are plane-polarized-light photomicrographs.

\subsubsection{Interstitial Components}

The matrix distribution is irregular, ranging from $1 \%$ to $20 \%$ of the total sandstones components and the siliciclastic matrix is dominant over the carbonate one, identified as micrite (CMx, Appendix A; Table 2; Figure 3A). Some samples are carbonate cemented with small amounts of ferruginous authigenic phases (Oxid-Fe cement in Table 1). Carbonate cementation occurs as scattered patchy areas of calcite filling pore spaces or replacing the framework's detrital grains. Sporadic zeolite grains, with radial-fibrous fabric, arranged in sub-spherical grains, have been recognized in four sandstone samples (Appendix A; Figure $7 \mathrm{G}, \mathrm{H})$.

\subsubsection{Modal Compositions}

The studied samples showed considerable variation in composition and they are scattered from the litharenite to the arkose fields of the triangular plot (Figure 3B). The distribution points highlight the source rocks' combined volcano and metamorphic/sedimentary clastic supply plotted as LmLvLs diagram (Figure 4A). This diagram shows a sharp contrast in the composition of the volcaniclastic interval, almost exclusively composed of volcanic 
fragments, and the siliciclastic beds occurring at the bottom and top, where the volcanic component is completely absent. An exception is represented by samples BE20-04, SP2 and SC1VG, representing the coarser beds among the volcaniclastic interval (at a microscope scale of observation). The detrital framework modes document changes in the detrital assemblage of the volcaniclastic lithic fragments. All samples are characterized by a higher proportion of shards with respect to pumices showing a minor amount of altered glass (Appendix A, Table 1). Relative proportions of Lv:M:S (e.g., [62]) (Figure 4B) show a great dispersion with clustering of data as a function of sediment gravity flows and energy, with a composition becoming lithic-rich (volcanic) basinward and more "sialic" in the proximal facies. The intermediate composition of the two Santa Caterina samples could represent an intermediate composition. Accumulation of heavy detrital minerals (M pole) is most likely present in samples transported by higher energy processes. In Figure $4 \mathrm{~B}$, the samples represented by green triangles (volcaniclastic bed) could be related to different events which involved volcaniclastic material, whereas the other samples have not involved volcaniclastic material.

\subsubsection{Diagenesis}

Important diagenetic processes include precipitation of carbonate cement followed by Fe-oxides cementation and minor physical compaction effects. In addition, precipitation of zeolite and partial replacements of rock fragments or silicate minerals such as feldspars by clay minerals also occurred (e.g., Figures 6C,D and 8C). No significant physical compaction occurred as neither squeezing of soft volcanic grains nor micas and phyllite fragments have produced pseudomatrix (e.g., [55]). The heavy minerals diversity is high (Appendix A) and thus these have not suffered great depths of burial. Unstable (pyroxene and amphibole) and moderately stable (epidote, garnet, sillimanite) heavy detrital species did not disappear by intrastratal dissolution (e.g., [71,72]) and they lacked etch-pits produced during dissolutionreprecipitation processes (e.g., [70,73]). Specifically, the distribution of amphibole limits the burial depth to between $600 \mathrm{~m}$ (e.g., [71]) and $2000 \mathrm{~m}$ (e.g., [72]). Zeolites were also recognized petrographically in some of the samples from the Santa Caterina locality. The content of zeolites ranged from about $0.2 \%$ to $0.8 \%$. Conditions favorable to zeolitization are provided by ash deposited in water or by a rise in temperature associated with marine diagenesis (e.g., [74]), or may also constitute a replacement of plagioclase and K-feldspars (e.g., [75]).

\subsection{Features of Volcanic Grains}

The volcanic fragments are made up of glass and crystals. Crystal fragments of volcanic provenance are mainly represented by both ortho and clinopyroxene. Glass is made up of shards (Figure 6D-H) and pumice fragments (Figure 6D-G). SEM images of thin sections revealed that glass is almost fresh without significant evidence of alteration into clay minerals. Moreover, SEM observation showed that glass occurs in the shape of shards and micro-pumices (Figure 8A), ranging in size from 10 to $190 \mu \mathrm{m}$ (maximum diameter). In particular, glass fragments of BE fine volcaniclastic beds (BE1VF, BE-20-05 samples) are represented only by shards of 10-60 $\mu \mathrm{m}$ (Figure $8 \mathrm{~B}$ ), while in BE coarse volcaniclastic beds (BE1VG, BE-20-04) both shard and pumice, ranging from 30 to $190 \mu \mathrm{m}$ in size, occur (Figure 8C). In S. Pietro in Amantea (SP) site, the glass fragments within the finer pack of volcaniclastic beds (SP1, SP-20-01 samples) are represented by shards ranging in size from 25 to $40 \mu \mathrm{m}$ (Figure 8D). S. Caterina fine-grained volcaniclastic beds display glass fragments ranging in size between 10 to $87 \mu \mathrm{m}$ (SC-20-05, SC-20-7). 

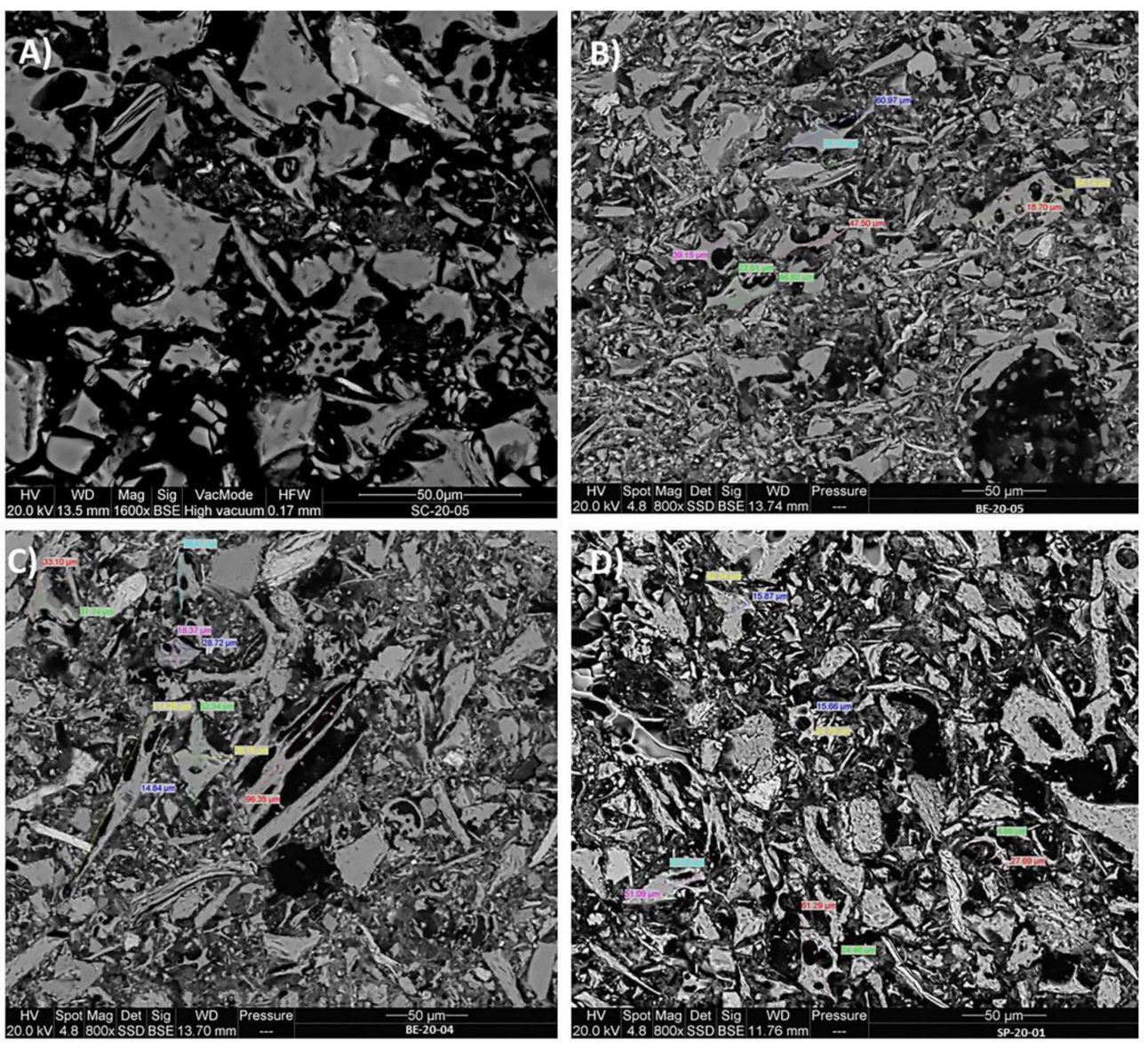

Figure 8. Micro-texture of volcanic glass fragments under SEM. (A) Shards and micro-pumices. (B) fine-grained volcaniclastic bed of BE outcrop (BE-20-05). (C) Coarse-grained volcaniclastic bed of BE outcrop (BE-20-04). (D) SP volcaniclastic bed (SP-20-01).

\subsection{Major Element Composition of Glass and Crystals}

Major element composition was obtained for glass and main mineral phases through EPMA-WDS analyses (Appendixes B and C). Glass composition has been classified based on the TAS diagram [76]. It can be observed that Amantea glass fragments show a narrow $\mathrm{SiO}_{2}$ range $\left(76 \mathrm{wt} \%<\mathrm{SiO}_{2}<77.75 \mathrm{wt} \%\right.$ ) and plot in the rhyolite field (Figure $9 \mathrm{~A}$ ) of the TAS diagram.
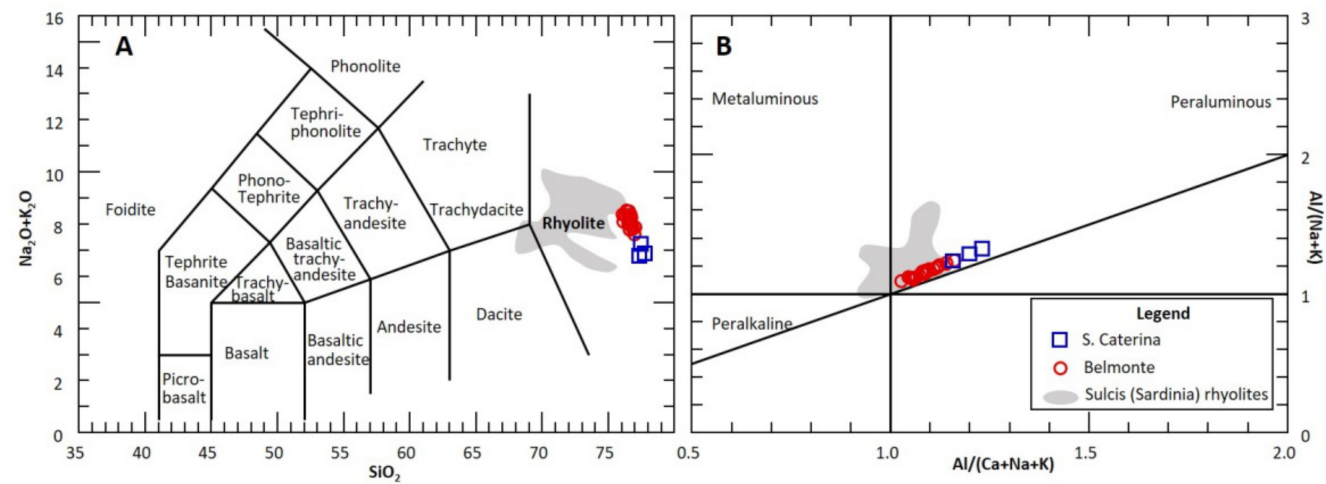

Figure 9. (A) TAS diagram [76] and (B) Shand's index [77] of volcanic glass fragments of BE (red circle) and SC (blue square) outcrops, compared to Sardinian products of late Oligo-Miocenic volcanism of Sulcis area (grey area) [78,79]. 
$\mathrm{SiO}_{2}$ content displays a slight increment from $\mathrm{BE}$ to $\mathrm{S}$. Caterina samples. However, as it is also accompanied by a slight decrease in alkalis and an increase in $\mathrm{Al}$, it could be related to a certain degree of weathering of Santa Caterina glass.

The glass composition of Belmonte samples partially overlaps with the products of the Oligo-Miocenic magmatic activity of Sardinia. In particular, we selected rhyolite rocks of the Sulcis and Logudoro-Bosano area with age approximately similar (21-15 Ma, [78]) and late Eocene-middle Miocene volcanism products (38.28 $\pm 0.26-12.24 \pm 0.98 \mathrm{Ma}$, [79]) or rhyolite rocks of the pre-comenditic Superior Sequence of Sulcis form S. Antioco, S. Pietro and Sulcis area [79]. Shand's index diagram (Figure 9B) [77] shows that glass fragments of Amantea Basin are in the peraluminous field. Thus, Belmonte samples overlap with Sardinian products, while S. Caterina evolves toward more peraluminous values.

Minerals of volcaniclastic origin detected in the samples are represented by pyroxenes composed of both clino- and ortho-pyroxenes (Figure 10).

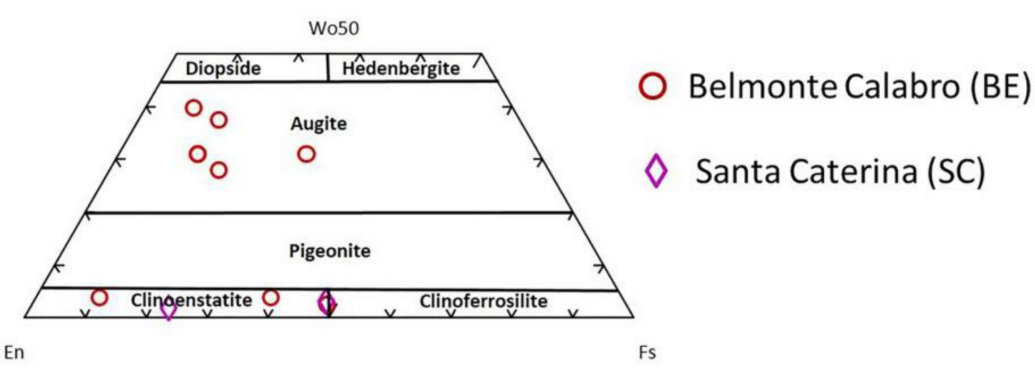

Figure 10. En-Wo-Fs classification diagram for pyroxenes. Analytical data are available in Appendix C.

\section{Discussion}

Volcanic eruptions and their products constitute a relevant factor in sedimentary control in basins not directly related to volcanic activity [80]. The volcaniclastic interval of the Amantea Basin testifies to the effect of volcanism in producing huge volumes of sediments in short time periods, greatly affecting the sediment yield and the depositional environment of the sedimentary basin.

Field observations and the stratigraphic and sedimentological characteristics of the beds suggest the sudden supply of the volcanic material into the basin by pyroclastic flows or direct falls and then rapid re-sedimentation by turbulent flows. The volcaniclastic interval is composed of several depositional units (Figure 5C), each consisting of a pair of coarse and fine beds. The coarser part is massive or normally graded and shows a mixed siliciclastic and volcanic composition. In contrast, the upper finer part is composed mainly of volcanic grains, as supported by modal analyses (Figure 4A, samples: BE1VF, SC-20-05, SC-20-06, SC-20-07, SC-20-09 and Table 2). By plotting the modal composition of samples in an Lv-M-S ternary diagram (Lv: all volcanic lithic textures; M: mafic and S: sialic single-crystal grains) the enrichments trend of the Lv component from the basal coarser volcanic and siliciclastic beds (Figures 2B and 4B: BE1VG, SC1VG, BE-20-02, SP2, SC-20-03, SC-20-04, SC-20-08, SC-20-10) to the finer ash beds at the top (Figure 4B: BE1VF, SC-20-05, SC-20-7) is evident. Then, each depositional unit's textural and compositional characteristics suggest the deposition of turbulent flows formed by a sudden large sediment influx into the basin caused by the remobilization of thick stockpiles of easily erodible, loose pyroclastic deposits. The relative abundance of the volcanic component in the finer grain size is due to the hydraulic selection during transport and deposition.

Petrographic analysis confirms that the nature of both framework detrital grains and the interstitial matrix of the Amantea Basin arenites are characterized by an association of multiple source rocks (e.g., [81,82]): a felsitic volcanic source, a sedimentary source of both siliciclastic and carbonate composition, and a crystalline source. Groupings of the recognized clastic supplies (Figures 3 and 4 ) include distinctive provenance settings (e.g., [83]) shed as siliciclastic sediment, during the late Tortonian-early Messinian, into 
the syn-rift Amantea Basin (e.g., $[84,85])$. In the latter, a volcaniclastic interval is almost exclusively derived from an undissected magmatic arc (e.g., [83]). Specifically, the volcanic interval at outcrop, consisting of abundant pumice and shard grains and subordinate altered volcanic glass, was mainly derived directly through explosive volcanism by pyroclastic fall of volcanic ash after one or more eruption episodes. The mixture of volcanic and plutonic/gneissic detritus, and the record of a progressive increase toward an arkosic composition of the arenites along the sedimentary succession (Figure 3B), indicate the main provenance to be from a source area exposing deep-seated crustal block and sedimentary cover.

Micro-textural observation under SEM verifies that the volcanic grains are made up of pumices, shards and single crystals. The fragments' textural and composition suggests an origin from sub-aerial explosive eruption and a primary deposition in a shallow marine environment before resedimentation. The rhyolitic composition and calcalkaline affinity of volcanic glasses and the age of the sedimentary succession in which the studied volcaniclastic interval is interbedded, prompt the late stages of Oligo-Miocenic Sardinian magmatic activity as the most probable source for volcanic material, as also witnessed by the partial overlapping with the chemical composition of these products with the Amantea glass. Petrographic analyses and the presence of both clinopyroxene and orthopyroxene support the hypothesis of a magmatic arc provenance. The source volcano had to be located relatively close to the marine basin allowing pyroclastic fragments and their remobilization by secondary flows. Moving from Belmonte Calabro (BE) to San Pietro (SP) and Santa Caterina (SC) outcrops, an overall decrease of the ash beds grainsize is observed. Sedimentological features give inference for proximal facies (slope/inner fan) for BE outcrop and distal facies for SP and SC (outer fan). Moreover, the overall prevalence of fine ash deposits hints at an original elongate shape of the basin, parallel to the eruptive vents, since the suspended load tends to be deposited laterally towards the banks. The rarity of coarse-grained ash deposit excludes the possibility for an orthogonal position of the basis to the vents. Trace elements composition of glass fragments will help for future and more precise correlations.

The studied volcaniclastic interval in the Serravallian succession of the Amantea Basin is a lithostratigraphic marker for the geodynamic evolution of the Amantea and the entire Tyrrhenian Basins. The lack of such an horizon in the other coeval peri-Tyrrhenian basins allows us to consider the Amantea Basin to be a confined elongated coastal basin, whose tectonostratigraphic architecture denotes a structural partitioning of the nascent back-arc Tyrrhenian Basin. The position of the volcanic system is probably on the eastern edge of Sardinia which has become a passive margin starting the Serravallian. It was progressively destroyed by the Tortonian extensional domino type tectonics and by the progressive subduction hinge retreat.

Author Contributions: Conceptualization, D.R.R. and M.F.; Data curation, C.C.B. and D.P.; Formal analysis, M.C. and C.C.B.; Funding acquisition, D.R.R.; Investigation, C.C.B., D.R.R., D.P., M.C. and M.F.; Methodology, C.C.B., D.P. and M.C.; Supervision, D.R.R. and M.F.; Validation, D.R.R., D.P. and M.F.; Writing-original draft, C.C.B., D.R.R., D.P., M.C. and M.F. All authors have read and agreed to the published version of the manuscript.

Funding: This research received no external funding.

Acknowledgments: The authors greatly thank Mariano Davoli from the Centre of Microscopy and Microanalysis (CM2) of the University of Calabria for his assistance during the SEM and microprobe analysis. The authors also thank the discussions with E. Le Pera who kindly provided advice and useful constructive critical comments during the arenites point-counting.

Conflicts of Interest: The authors declare no conflict of interest. 


\section{Appendix A}

Table A1. Point counting raw data. Key to counted and recalculated parameters are shown in Tables 1 and 2.

\begin{tabular}{|c|c|c|c|c|c|c|c|c|c|c|c|c|c|c|c|c|c|c|c|c|c|c|}
\hline SAMPLE & $\mathrm{Qm}$ & $Q p$ & Qp-tf & Ch & $\underset{\text { Rg }}{\text { Qm in }}$ & $\begin{array}{c}\text { Qp in } \\
\text { Rg }\end{array}$ & $\underset{\mathrm{Rs}}{\mathrm{Qm} \text { in }}$ & $\mathbf{K}$ & $\begin{array}{c}\mathrm{K} \text { in } \\
\mathbf{R g}\end{array}$ & $\begin{array}{c}\mathrm{K} \text { in } \\
\mathrm{Rs}\end{array}$ & $\mathbf{P}$ & $\begin{array}{c}\mathrm{P} \text { in } \\
\mathrm{Rg}\end{array}$ & AF-C & AF-Ser & $\begin{array}{c}\mathrm{AF} \text { in } \\
\mathrm{Rg}\end{array}$ & $\mathrm{Bt}$ & $\begin{array}{c}\text { Bt in } \\
\text { Rg }\end{array}$ & $\mathrm{Mu}$ & $\begin{array}{c}\mathrm{Mu} \text { in } \\
\mathrm{Rg}\end{array}$ & Chl & $\begin{array}{l}\mathrm{ABt} / \\
\mathrm{AMu}\end{array}$ & G1 \\
\hline SP2 & 107 & 17 & 4 & 4 & 0 & 0 & 0 & 33 & 0 & 0 & 31 & 0 & 0 & 30 & 0 & 58 & 0 & 35 & 0 & 5 & 14 & 2 \\
\hline BE1VG & 62 & 3 & 1 & 2 & 0 & 0 & 0 & 14 & 0 & 0 & 13 & 0 & 0 & 42 & 0 & 25 & 0 & 10 & 0 & 8 & 11 & 0 \\
\hline BE1VF & 5 & 0 & 0 & 0 & 0 & 0 & 0 & 1 & 0 & 0 & 0 & 0 & 0 & 2 & 0 & 8 & 0 & 3 & 0 & 0 & 0 & 0 \\
\hline BE20-02 & 80 & 14 & 1 & 0 & 2 & 0 & 0 & 62 & 4 & 0 & 42 & 6 & 20 & 40 & 0 & 40 & 6 & 6 & 0 & 2 & 8 & 2 \\
\hline BE20-4 & 93 & 13 & 1 & 0 & 9 & 0 & 0 & 31 & 5 & 0 & 48 & 5 & 6 & 38 & 3 & 23 & 3 & 8 & 0 & 5 & 8 & 1 \\
\hline SC1VG & 80 & 23 & 1 & 1 & 8 & 0 & 0 & 33 & 1 & 0 & 36 & 1 & 0 & 25 & 0 & 39 & 0 & 18 & 0 & 4 & 6 & 1 \\
\hline SC20-03 & 108 & 18 & 0 & 2 & 4 & 0 & 0 & 68 & 2 & 0 & 42 & 2 & 12 & 42 & 4 & 36 & 0 & 4 & 0 & 2 & 10 & 2 \\
\hline SC20-04 & 95 & 18 & 0 & 5 & 16 & 0 & 4 & 55 & 8 & 0 & 27 & 3 & 22 & 54 & 10 & 26 & 8 & 3 & 3 & 1 & 7 & 0 \\
\hline SC20-05 & 31 & 3 & 0 & 0 & 0 & 0 & 0 & 12 & 0 & 0 & 3 & 0 & 3 & 7 & 0 & 28 & 0 & 19 & 0 & 2 & 8 & 0 \\
\hline SC20-06 & 44 & 11 & 0 & 2 & 0 & 0 & 0 & 20 & 0 & 0 & 28 & 0 & 13 & 30 & 0 & 36 & 0 & 14 & 0 & 6 & 15 & 3 \\
\hline SC20-07 & 18 & 0 & 0 & 0 & 0 & 0 & 0 & 8 & 0 & 0 & 4 & 0 & 0 & 2 & 0 & 4 & 0 & 0 & 0 & 2 & 4 & 6 \\
\hline SC20-08 & 98 & 30 & 2 & 2 & 4 & 0 & 0 & 38 & 2 & 0 & 28 & 0 & 16 & 20 & 0 & 34 & 0 & 10 & 0 & 3 & 9 & 4 \\
\hline SC20-09 & 66 & 20 & 0 & 2 & 0 & 0 & 0 & 26 & 0 & 0 & 18 & 0 & 0 & 28 & 0 & 22 & 0 & 18 & 0 & 8 & 24 & 2 \\
\hline SC20-10 & 76 & 40 & 2 & 10 & 24 & 12 & 8 & 68 & 16 & 2 & 40 & 2 & 14 & 48 & 10 & 16 & 2 & 2 & 0 & 6 & 10 & 6 \\
\hline SAMPLE & Py & Py in $R g$ & APy & Amph & $\begin{array}{c}\text { Amph } \\
\text { in Rg }\end{array}$ & Aamph & Gr & $\mathrm{Zr}$ & To & $\mathbf{R u}$ & Ep & Sill & $\operatorname{Hm}(o p)$ & Und(Hm) & Cal & $\begin{array}{c}\text { Carb on } \\
\text { Und }\end{array}$ & Lscmicr & OvsLscmicr & Lsccrist & Lss & Lm & Lvf \\
\hline SP2 & 0 & 0 & 0 & 2 & 0 & 0 & 0 & 3 & 1 & 2 & 3 & 0 & 2 & 0 & 7 & 5 & 19 & 2 & 13 & 11 & 7 & 0 \\
\hline BE1VG & 0 & 0 & 0 & 0 & 0 & 0 & 0 & 4 & 0 & 0 & 0 & 0 & 8 & 0 & 0 & 0 & 5 & 3 & 0 & 20 & 3 & 0 \\
\hline BE1VF & 0 & 0 & 0 & 0 & 0 & 0 & 0 & 0 & 0 & 0 & 0 & 0 & 3 & 0 & 0 & 0 & 0 & 0 & 0 & 0 & 0 & 0 \\
\hline BE20-02 & 4 & 0 & 0 & 6 & 0 & 0 & 0 & 0 & 0 & 0 & 0 & 2 & 10 & 4 & 6 & 0 & 0 & 2 & 0 & 2 & 4 & 0 \\
\hline BE20-4 & 1 & 0 & 2 & 12 & 1 & 2 & 14 & 2 & 0 & 2 & 1 & 5 & 12 & 1 & 0 & 2 & 1 & 0 & 0 & 2 & 5 & 0 \\
\hline SC1VG & 0 & 0 & 0 & 9 & 0 & 0 & 0 & 2 & 2 & 2 & 1 & 0 & 2 & 8 & 0 & 0 & 1 & 0 & 0 & 9 & 14 & 2 \\
\hline SC20-03 & 0 & 0 & 0 & 12 & 0 & 0 & 2 & 0 & 0 & 4 & 0 & 0 & 22 & 2 & 0 & 0 & 0 & 0 & 0 & 2 & 2 & 0 \\
\hline SC20-06 & 0 & 0 & 0 & 4 & 0 & 0 & 0 & 0 & 0 & 0 & 0 & 0 & 6 & 0 & 5 & 3 & 0 & 1 & 0 & 1 & 0 & 0 \\
\hline SC20-07 & 0 & 0 & 0 & 2 & 0 & 0 & 0 & 1 & 0 & 0 & 0 & 0 & 24 & 0 & 0 & 0 & 2 & 0 & 0 & 0 & 0 & 0 \\
\hline SC20-08 & 0 & 0 & 0 & 0 & 0 & 0 & 0 & 1 & 0 & 2 & 0 & 0 & 11 & 0 & 0 & 2 & 0 & 0 & 0 & 0 & 5 & 0 \\
\hline SC20-09 & 0 & 0 & 0 & 1 & 0 & 0 & 0 & 0 & 0 & 0 & 0 & 0 & 6 & 0 & 0 & 0 & 0 & 0 & 0 & 0 & 2 & 0 \\
\hline SC20-10 & 0 & 0 & 0 & 10 & 0 & 0 & 6 & 0 & 0 & 2 & 6 & 2 & 12 & 0 & 8 & 0 & 2 & 0 & 6 & 4 & 8 & 0 \\
\hline SAMPLE & ALvl & Shard & $\mathrm{Pm}$ & APm & Aglass & Bio & Zeo & SilMx & CMx & CC & Ox-Fe-C & Und & Tot & & & & & & & & & \\
\hline SP2 & 0 & 4 & 0 & 0 & 1 & 13 & 0 & 23 & 14 & 18 & 5 & 5 & 500 & & & & & & & & & \\
\hline BE1VG & 0 & 119 & 38 & 51 & 4 & 0 & 0 & 42 & 2 & 0 & 9 & 1 & 500 & & & & & & & & & \\
\hline BE1VF & 0 & 41 & 17 & 0 & 0 & 0 & 0 & 3 & 0 & 0 & 17 & 0 & 100 & & & & & & & & & \\
\hline BE20-02 & 0 & 0 & 0 & 0 & 0 & 6 & 0 & 0 & 4 & 114 & 0 & 1 & 500 & & & & & & & & & \\
\hline BE20-4 & 2 & 43 & 6 & 0 & 1 & 0 & 0 & 20 & 6 & 35 & 20 & 2 & 500 & & & & & & & & & \\
\hline SC1VG & 2 & 29 & 13 & 2 & 0 & 1 & 2 & 96 & 0 & 0 & 24 & 2 & 500 & & & & & & & & & \\
\hline SC20-03 & 0 & 0 & 0 & 0 & 0 & 0 & 0 & 18 & 2 & 0 & 76 & 0 & 500 & & & & & & & & & \\
\hline SC20-04 & 0 & 0 & 0 & 0 & 0 & 0 & 0 & 2 & 13 & 48 & 2 & 3 & 500 & & & & & & & & & \\
\hline SC20-05 & 0 & 131 & 79 & 0 & 0 & 6 & 1 & 101 & 0 & 4 & 51 & 0 & 500 & & & & & & & & & \\
\hline SC20-06 & 0 & 80 & 49 & 6 & 0 & 3 & 2 & 13 & 3 & 84 & 15 & 3 & 500 & & & & & & & & & \\
\hline SC20-07 & 0 & 112 & 56 & 16 & 0 & 10 & 0 & 68 & 0 & 2 & 159 & 0 & 500 & & & & & & & & & \\
\hline SC20-08 & 0 & 0 & 0 & 0 & 0 & 0 & 0 & 0 & 12 & 162 & 4 & 1 & 500 & & & & & & & & & \\
\hline SC20-09 & 0 & 99 & 62 & 6 & 0 & 12 & 4 & 20 & 4 & 20 & 30 & 0 & 500 & & & & & & & & & \\
\hline SC20-10 & 0 & 0 & 0 & 0 & 0 & 4 & 0 & 0 & 6 & 4 & 4 & 2 & 500 & & & & & & & & & \\
\hline
\end{tabular}




\section{Appendix B}

Table A2. Major element ( $w \mathrm{t} \%)$ compositions of glass fragments.

\begin{tabular}{|c|c|c|c|c|c|c|c|c|c|c|c|c|c|}
\hline Sample & $\mathrm{Na}_{2} \mathrm{O}$ & $\mathrm{MgO}$ & $\mathrm{SiO}_{2}$ & $\mathrm{Al}_{2} \mathrm{O}_{3}$ & $\mathrm{~K}_{2} \mathrm{O}$ & $\mathrm{Cl}$ & $\mathrm{CaO}$ & $\mathrm{FeO}$ & $\mathrm{TiO}_{2}$ & $\mathrm{P}_{2} \mathrm{O}_{5}$ & $\mathrm{MnO}$ & $\mathrm{Cr}_{2} \mathrm{O}_{3}$ & SUM \\
\hline BE20-05_001 & 4.34 & 0.05 & 76.13 & 12.74 & 4.01 & 0.41 & 0.35 & 1.55 & 0.30 & 0.06 & 0.04 & 0.01 & 100 \\
\hline BE20-05_003 & 4.21 & 0.06 & 76.62 & 12.71 & 3.90 & 0.40 & 0.30 & 1.64 & 0.11 & 0.02 & 0.00 & 0.03 & 100 \\
\hline BE20-05_006 & 4.07 & 0.03 & 76.53 & 12.89 & 3.95 & 0.36 & 0.42 & 1.62 & 0.00 & 0.01 & 0.09 & 0.03 & 100 \\
\hline BE20-05_008 & 4.17 & 0.06 & 76.60 & 12.77 & 3.81 & 0.40 & 0.41 & 1.69 & 0.07 & 0.00 & 0.01 & 0.02 & 100 \\
\hline BE20-05_009 & 4.01 & 0.06 & 76.61 & 12.62 & 4.03 & 0.42 & 0.32 & 1.69 & 0.15 & 0.00 & 0.09 & 0.00 & 100 \\
\hline BE20-05_013 & 4.07 & 0.11 & 76.68 & 12.86 & 3.71 & 0.36 & 0.40 & 1.57 & 0.15 & 0.00 & 0.07 & 0.02 & 100 \\
\hline BE20-05_20 & 4.23 & 0.06 & 76.53 & 12.65 & 4.08 & 0.41 & 0.34 & 1.56 & 0.00 & 0.00 & 0.09 & 0.05 & 100 \\
\hline BE20-05_34 & 4.24 & 0.10 & 76.77 & 12.59 & 4.00 & 0.39 & 0.28 & 1.45 & 0.11 & 0.00 & 0.09 & 0.00 & 100 \\
\hline BE20-05_35 & 4.21 & 0.07 & 76.41 & 12.57 & 4.30 & 0.34 & 0.35 & 1.55 & 0.20 & 0.00 & 0.00 & 0.00 & 100 \\
\hline BE20-05_37 & 4.00 & 0.07 & 76.86 & 12.77 & 3.82 & 0.39 & 0.38 & 1.65 & 0.03 & 0.00 & 0.01 & 0.02 & 100 \\
\hline BE20-05_39 & 4.29 & 0.09 & 76.57 & 12.66 & 3.96 & 0.35 & 0.42 & 1.44 & 0.11 & 0.01 & 0.10 & 0.00 & 100 \\
\hline BE20-05_42 & 4.17 & 0.04 & 76.61 & 12.71 & 4.32 & 0.38 & 0.26 & 1.32 & 0.17 & 0.00 & 0.00 & 0.02 & 100 \\
\hline BE20-05_43 & 4.25 & 0.06 & 76.69 & 12.64 & 4.09 & 0.39 & 0.27 & 1.40 & 0.18 & 0.00 & 0.00 & 0.01 & 100 \\
\hline BE20-05_44 & 4.07 & 0.06 & 76.61 & 12.69 & 4.03 & 0.43 & 0.38 & 1.42 & 0.21 & 0.03 & 0.07 & 0.00 & 100 \\
\hline BE20-05_46 & 3.80 & 0.10 & 76.66 & 12.81 & 3.96 & 0.36 & 0.37 & 1.69 & 0.23 & 0.00 & 0.01 & 0.00 & 100 \\
\hline BE20-05_51 & 4.19 & 0.05 & 76.74 & 12.86 & 3.74 & 0.41 & 0.36 & 1.55 & 0.06 & 0.00 & 0.02 & 0.03 & 100 \\
\hline BE20-05_53 & 4.17 & 0.03 & 76.59 & 12.86 & 3.90 & 0.34 & 0.40 & 1.51 & 0.18 & 0.00 & 0.00 & 0.00 & 100 \\
\hline BE20-05_59 & 3.93 & 0.06 & 77.02 & 12.88 & 3.67 & 0.39 & 0.36 & 1.43 & 0.18 & 0.00 & 0.07 & 0.00 & 100 \\
\hline SC20-05_016 & 4.60 & 0.05 & 77.45 & 12.92 & 2.65 & 0.38 & 0.41 & 1.42 & 0.07 & 0.00 & 0.05 & 0.00 & 100 \\
\hline SC20-05_019 & 4.50 & 0.05 & 77.75 & 12.89 & 2.40 & 0.39 & 0.42 & 1.46 & 0.07 & 0.00 & 0.07 & 0.00 & 100 \\
\hline SC20-05_042 & 4.42 & 0.05 & 77.31 & 13.04 & 2.38 & 0.39 & 0.41 & 1.61 & 0.31 & 0.00 & 0.05 & 0.03 & 100 \\
\hline
\end{tabular}




\section{Appendix C}

Table A3. Major element compositions of pyroxene minerals.

\begin{tabular}{|c|c|c|c|c|c|c|c|c|c|c|c|c|c|c|c|c|c|c|c|c|c|c|c|c|c|c|c|c|c|c|c|c|}
\hline Sample & $\mathrm{SiO}_{2}$ & $\mathrm{TiO}_{2}$ & $\mathrm{Al}_{2} \mathrm{O}_{3}$ & $\mathrm{Cr}_{2} \mathrm{O}_{3}$ & $\mathrm{Fe}_{2} \mathrm{O}_{3}$ & $\mathrm{FeO}$ & MnO & $\mathrm{NiO}$ & MgO & CaO & $\mathrm{Na}_{2} \mathrm{O}$ & $\mathrm{K}_{2} \mathrm{O}$ & Sum & $\mathrm{Si}$ & $\mathrm{Al}$ & $\mathrm{Ti}$ & $\mathrm{Fe}_{3}+$ & $\mathrm{Al}$ & $\mathrm{Ti}$ & $\mathrm{Cr}$ & $\mathrm{Fe}_{3}+$ & $\mathrm{Mg}$ & $\mathrm{Ni}$ & $\mathrm{Fe}_{2}+$ & $\mathrm{Mn}$ & $\mathrm{Ca}$ & $\mathrm{Na}$ & K & En & $\mathrm{Fe}$ & Wo & $\mathrm{Mg}$ \\
\hline BE1VG_40-opx & 55.00 & 0.00 & 1.26 & 0.00 & 0.00 & 25.19 & 1.67 & 0.00 & 15.21 & 1.09 & 0.58 & 0.00 & 100.00 & 2.12 & -0.12 & 0.00 & 0.00 & 0.17 & 0.00 & 0.00 & 0.00 & 0.87 & 0.00 & 0.81 & 0.05 & 0.04 & 0.04 & 0.00 & 48.95 & 48.53 & 2.52 & 0.50 \\
\hline $\begin{array}{l}\text { BE1VF_27-opx } \\
\text { BE1VE 29-opx }\end{array}$ & 54.36 & $\begin{array}{l}0.00 \\
0.00\end{array}$ & $\begin{array}{l}1.70 \\
0.86\end{array}$ & 0.00 & 0.00 & 26.77 & 0.00 & 0.00 & $\begin{array}{l}15.37 \\
2605\end{array}$ & $\begin{array}{l}1.39 \\
0.93\end{array}$ & 0.42 & 0.00 & $\begin{array}{l}100.01 \\
10000\end{array}$ & 2.09 & $\begin{array}{l}-0.09 \\
-0.09 \\
-10\end{array}$ & 0.00 & 0.00 & 0.17 & 0.00 & 0.00 & 0.00 & 0.88 & 0.00 & 0.86 & 0.00 & 0.06 & 0.03 & 0.00 & $\begin{array}{l}48.97 \\
75.45\end{array}$ & $\begin{array}{l}47.85 \\
22.62\end{array}$ & $\begin{array}{l}3.18 \\
194\end{array}$ & 0.51 \\
\hline $\begin{array}{l}\text { BEIV-29-opx } \\
\text { BE1VG 34-cp }\end{array}$ & $\begin{array}{l}58.44 \\
51.44\end{array}$ & $\begin{array}{l}0.00 \\
1.89\end{array}$ & $\begin{array}{l}0.86 \\
7.10\end{array}$ & $\begin{array}{l}0.00 \\
0.00\end{array}$ & $\begin{array}{l}0.00 \\
0.00\end{array}$ & $\begin{array}{l}13.92 \\
9.84\end{array}$ & 0.00 & 0.00 & $\begin{array}{l}20.003 \\
16.57\end{array}$ & $\begin{array}{l}0.95 \\
11.87\end{array}$ & $\begin{array}{l}0.01 \\
0.81\end{array}$ & $\begin{array}{l}0.00 \\
0.49\end{array}$ & 100.01 & $\begin{array}{l}2.10 \\
1.89\end{array}$ & $\begin{array}{l}0.11 \\
0.11 \\
-110\end{array}$ & 0.00 & 0.00 & $\begin{array}{l}0.14 \\
0.19\end{array}$ & 0.05 & 0.00 & 0.00 & $\begin{array}{l}1.40 \\
0.91\end{array}$ & $\begin{array}{l}0.00 \\
0.00\end{array}$ & $\begin{array}{l}0.42 \\
030\end{array}$ & $\begin{array}{l}0.00 \\
0.00\end{array}$ & $\begin{array}{l}0.04 \\
0.47\end{array}$ & $\begin{array}{l}0.00 \\
0.06\end{array}$ & $\begin{array}{l}0.00 \\
0.02\end{array}$ & $\begin{array}{l}5.45 \\
54.15\end{array}$ & $\begin{array}{l}28.02 \\
1883\end{array}$ & $\begin{array}{l}1.94 \\
2786\end{array}$ & $\begin{array}{l}0.77 \\
0.75\end{array}$ \\
\hline BE1VG_41-cpx & 45.06 & 1.34 & 13.50 & $\begin{array}{l}0.00 \\
0.00\end{array}$ & 4.10 & $\begin{array}{l}9.04 \\
13.63 \\
\end{array}$ & $\begin{array}{l}0.00 \\
0.00\end{array}$ & 0.00 & $\begin{array}{l}1.076 \\
9.46\end{array}$ & $\begin{array}{l}1.8 \\
10.65\end{array}$ & $\begin{array}{l}0.71 \\
1.77\end{array}$ & $\begin{array}{l}0.99 \\
0.90\end{array}$ & 100.40 & 1.69 & 0.31 & 0.00 & 0.00 & 0.29 & 0.04 & 0.00 & 0.12 & 0.53 & 0.00 & 0.43 & 0.00 & 0.43 & 0.13 & 0.04 & 35.27 & $\begin{array}{l}36.20 \\
\end{array}$ & 28.53 & 0.49 \\
\hline SC1VG_17-opx & 56.89 & 0.00 & 0.88 & 0.60 & 0.00 & 7.04 & 0.00 & 0.00 & 32.51 & 2.00 & 0.00 & 0.00 & 99.92 & 1.98 & 0.02 & 0.00 & 0.00 & 0.02 & 0.00 & 0.02 & 0.00 & 1.69 & 0.00 & 0.20 & 0.00 & 0.07 & 0.00 & 0.00 & 85.79 & 10.42 & 3.79 & 0.89 \\
\hline SC1VG_26-opx & 56.25 & 0.00 & 0.75 & 0.00 & 0.00 & 22.24 & 0.00 & 0.00 & 18.63 & 1.68 & 0.45 & 0.00 & 100.00 & 2.12 & -0.12 & 0.00 & 0.00 & 0.15 & 0.00 & 0.00 & 0.00 & 1.05 & 0.00 & 0.70 & 0.00 & 0.07 & 0.03 & 0.00 & 57.65 & 38.61 & $\begin{array}{l}3.74 \\
3.74\end{array}$ & 0.60 \\
\hline SCIVG_020001)-cpx & $\begin{array}{l}46.80 \\
53.17\end{array}$ & $\begin{array}{l}1.54 \\
0.00\end{array}$ & $\begin{array}{l}9.80 \\
5.45\end{array}$ & 0.00 & $\begin{array}{l}5.18 \\
0.00\end{array}$ & $\begin{array}{l}6.63 \\
7.75\end{array}$ & 0.00 & 0.00 & 18.64 & $\begin{array}{l}144.62 \\
14.29\end{array}$ & $\begin{array}{l}1.15 \\
0.70\end{array}$ & $\begin{array}{l}0.02 \\
0.00\end{array}$ & $\begin{array}{l}100.23 \\
100.00\end{array}$ & $\begin{array}{l}1.73 \\
1.92\end{array}$ & 0 & 0.00 & $\begin{array}{l}0.00 \\
0.00\end{array}$ & $\begin{array}{l}0.15 \\
0.16\end{array}$ & $\begin{array}{l}0.04 \\
0.00\end{array}$ & 0.000 & $\begin{array}{l}0.14 \\
0.00\end{array}$ & 6 & $\begin{array}{l}0.00 \\
000\end{array}$ & 0.20 & $\begin{array}{l}0.00 \\
0.00\end{array}$ & 年 & $\begin{array}{l}0.08 \\
0.05\end{array}$ & 00 & $\begin{aligned} 45.20 \\
5600\end{aligned}$ & $\begin{array}{l}20.01 \\
1.307\end{array}$ & $\begin{array}{r}34.19 \\
3089\end{array}$ & 0.69 \\
\hline SCIVG_028-cpx & 46.80 & 0.00 & 9.68 & 0.00 & $\begin{array}{l}0.007 \\
10.77\end{array}$ & 3.58 & 0.00 & 0.00 & 13.08 & 13.80 & 1.89 & 0.86 & 100.46 & $\begin{array}{l}1.92 \\
1.73\end{array}$ & 0.27 & $\begin{array}{l}0.00 \\
0.00\end{array}$ & 0.00 & $\begin{array}{l}0.16 \\
0.15\end{array}$ & $\begin{array}{l}0.00 \\
0.00\end{array}$ & 0.00 & 0.30 & $\begin{array}{l}1.72 \\
0.72\end{array}$ & $\begin{array}{l}0.00 \\
0.00\end{array}$ & 0.11 & 0.00 & $\begin{array}{l}0.55 \\
0.55\end{array}$ & $\begin{array}{l}0.14 \\
0.14\end{array}$ & $\begin{array}{l}0.04 \\
0.04\end{array}$ & $\begin{array}{l}56.93 \\
42.97\end{array}$ & $\begin{array}{l}13.45 \\
24.07\end{array}$ & $\begin{array}{l}32.58 \\
32.58\end{array}$ & $\begin{array}{l}0.61 \\
0.64\end{array}$ \\
\hline
\end{tabular}




\section{References}

1. Fisher, R.V.; Schmincke, H.-U. Volcaniclastic sediment transport and deposition. In Sediment Transport and Depositional Processes; Pye, K., Ed.; Blackwell Scientific Publications: Oxford, UK, 1994; pp. 351-388.

2. Königer, S.; Stollhofen, H. Environmental and Tectonic Controls on Preservation Potential of Distal Fallout Ashes in FluvioLacustrine Settings: The Carboniferous-Permian Saar-Nahe Basin, South-West Germany. Spec. Publs. Int. Ass. Sediment 2001, 30, 263-284.

3. Fisher, R.V.; Schmincke, H.-U. Pyroclastic Rocks; Springer: Berlin/Heidelberg, Germany, $1984 ;$ p. 472.

4. White, J.D.L.; Houghton, B.F. Primary volcaniclastic rocks. Geology 2006, 34, 677-680. [CrossRef]

5. Sohn, C.; Sohn, Y.K. Distinguishing between primary and secondary volcaniclastic deposits. Sci. Rep. 2019, 9, 12425. [CrossRef] [PubMed]

6. Carey, S.N.; Schneider, J.L. Volcaniclastic processes and deposits in the deep sea. In Developments in Sedimentology; Hüneke, H., Mulder, T., Eds.; Elsevier: Oxford, UK, 2011; Volume 63, pp. 457-515.

7. Di Capua, A.; De Rosa, R.; Kereszturi, G.; Le Pera, E.; Rosi, M.; Watt, S. From volcanoes to sediments: Bridging the terminological gap between volcanology and sedimentology. In Volcanic Processes in the Sedimentary Record: When Volcanoes Meet the Environment; GSL Special publication: London, UK, 2021.

8. Di Nocera, S.; Ortolani, F.; Russo, M.; Torre, M. Successioni sedimentarie messiniane e limite Miocene-Pliocene nella Calabria settentrionale. Boll. Soc. Geol. Ital. 1974, 93, 575-607.

9. Ortolani, F.; Torre, M.; Di Nocera, S. I depositi altomiocenici del bacino di Amantea (Catena Costiera Calabra). Boll. Soc. Geol. Ital. 1979, 98, 559-587.

10. Tansi, C. La tettonica recente dell'area di Amantea (Catena Costiera, Calabria). Rend. Soc. Geol. Ital. 1991, 14, 185-188.

11. Argentieri, A.; Mattei, M.; Rossetti, F.; Argnani, A.; Salvini, F.; Funiciello, R. Tectonic evolution of the Amantea basin (Calabria, Southern Italy): Comparing in-land and off- shore data. Ann. Tect. 1998, 12, 79-96.

12. Colella, A.; Longhitano, S. Il bacino di Amantea: Una possibile chiave di lettura della Stretta di Catanzaro. In Proceedings of the GEOITALIA $1^{\circ}$ Forum Fist, Rimini, Italy, 5-9 October 1997; Società Italiana di Mineralogia e Petrologia: Pisa, Italy, 1997; Volume 2, pp. 28-29.

13. Longhitano, S.; Colella, A. Tettonica transpressiva tortoniana nel Bacino di Amantea (Calabria) e record sedimentario. In Proceedings of the Atti Della Riunione Annuale del GIS, Bologna, Italy, 6-9 October 1998; G. Geol.: Bologna, Italy, 1998; Volume 60, pp. 45-47.

14. Mattei, M.; Speranza, F.; Argentieri, A.; Rossetti, F.; Sagnotti, L.; Funiciello, R. Extensional tectonics in the Amantea Basin (Calabria, Italy): A comparison between structural and magnetic anisotropy data. Tectonophysics 1999, 307, 33-49. [CrossRef]

15. Speranza, F.; Mattei, M.; Sagnotti, L.; Grasso, F. Paleomagnetism of upper Miocene sediments from the Amantea basin (Calabria, Italy): Rotational differences between the northern and southern Tyrrhenian domains. J. Geol Soc. Lond. 2000, 157, 327-334. [CrossRef]

16. Martini, I.P.; Sagri, M.; Colella, A. Neogene-Quaternary basins of the inner Apennines and Calabrian arc. In Anatomy of an Orogen: The Apennines and Adjacent Mediterranean Basin; Vai, G.B., Martini, I.P., Eds.; Kluwer Academic Publishers: Dordrecht, The Netherlands, 2001; pp. 375-400.

17. Muto, F.; Perri, E. Evoluzione tettono-sedimentaria del bacino di Amantea, Calabria occidentale (Tectonic-sedimentary evolution of the Amantea basin, western Calabria). Boll. Soc. Geol. Ital. 2002, 121, 1-19.

18. Mattei, M.; Cipollari, P.; Cosentino, D.; Argentieri, A.; Rossetti, F.; Speranza, F.; Di Bella, L. The Miocene tectono-sedimentary evolution of the southern Tyrrhenian Sea: Stratigraphy, structural and paleomagnetic data from the on shore Amantea basin (Calabrian Arc, Italy). Basin Res. 2002, 14, 147-168. [CrossRef]

19. Longhitano, S.G.; Nemec, W. Statistical analysis of bed-thickness variation in a Tortonian succession of biocalcarenitic tidal dunes, Amantea Basin, Calabria, southern Italy. Sedim. Geol. 2005, 179, 195-224. [CrossRef]

20. Boggs, S. Experimental study of rock fragments. J. Sediment. Petrol. 1968, 38, 1326-1339.

21. Alvarez, W.; Cocozza, T.; Wezel, F.C. Fragmentation of the Alpine orogenic belt by microplate dispersal. Nature 1974, 248, 309-314. [CrossRef]

22. Rossetti, F.; Faccenna, C.; Goff, P.; Moni, P.; Argentieri, A.; Funiciello, R.; Mattei, M. Alpine structural and metamorphic segnature of the Sila Piccola Massif nappe stack (Calabria, Italy): Insights for a tectonic evolution of the Calabrian Arc. Tectonics 2001, 20, 112-133. [CrossRef]

23. Ogniben, L. Schema introduttivo alla geologia del confine calabro-lucano. Mem. Soc. Geol. Ital. 1969, 8, $453-763$.

24. Dewey, J.F.; Helman, M.L.; Turco, E.; Hutton, D.H.W.; Knott, S.D. Kinematics of the western Mediterranenan. In Alpine Tectonics; Coward, M.P., Dietrich, D., Park, R.G., Eds.; Geological Society Special Publications: London, UK, 1989; Volume 45, pp. 265-283.

25. Knott, S.D.; Turco, E. Late Cenozoic kinematics of the Calabrian Arc, southern Italy. Tectonics 1991, 10, 1164-1172. [CrossRef]

26. Bouillin, J.P. Nouvelle interprétation de la liaison Apennin-Magrébides en Calabre: Conséquences sur la paléogéographie téthysienne entre Gibraltar et les Alpes. Rev. Geol. Dyn. Geogr. Phys. 1984, 25, 321-338.

27. Bouillin, J.P.; Durand-Delga, M.; Oliver, P.H. Betic- Rifian and Tyrrhenian arcs: Distinctive features, genesis and development stage. In The Origin of Arcs; Wezel, C.F., Ed.; Elsevier: Amsterdam, The Netherlands, 1986; pp. $281-304$. 
28. Dietrich, D. Sense of overthrust shear in the Alpine nappes of Calabria (Southern Italy). J. Struct. Geol. 1988, 10, 373-381. [CrossRef]

29. Amodio Morelli, L.; Bonardi, G.; Colonna, V.; Dietrich, D.; Giunta, G.; Ippolito, F.; Liguori, V.; Lorenzoni, S.; Paglionico, A.; Perrone, V.; et al. L'arco calabro-peloritano nell'orogene appenninico-maghrebide. Mem. Soc. Geol. Ital. 1976, 17, 1-60.

30. Haccard, D.; Lorenz, C.; Grandjacquet, C. Essai sur l'evolution tectogénètique de la liaison Alpes-Apennines (de la Ligurie à la Calabre). Mem. Soc. Geol. Ital. 1972, 11, 309-341.

31. Doglioni, C.; Mongelli, F.; Pialli, P. Boudinage of the Alpine belt in the Apenninic back-arc. Mem. Soc. Geol. Ital. 1998, 52, 457-468.

32. Malinverno, A.; Ryan, W.B.F. Extension in the Tyrrhenian Sea and shortening in the Apennines as result of arc migrationdriven by sinking of the lithosphere. Tectonics 1986, 5, 227-245. [CrossRef]

33. Decandia, F.A.; Lazzarotto, A.; Liotta, D.; Cernobori, L.; Nicolich, R. The CROP03 traverse: Insights on post-collisional evolution of Northern Apennines. Mem. Soc. Geol. Ital. 1998, 52, 427-439.

34. Brutto, F.; Muto, F.; Loreto, M.F.; De Paola, N.; Tripodi, V.; Critelli, S.; Facchin, L. The Neogene-Quaternary geodynamic evolution of the central Calabrian Arc: A case study from the western Catanzaro Trough basin. J. Geodyn. 2016, 102, 95-114. [CrossRef]

35. Muto, F.; Critelli, S.; Robustelli, G.; Tripodi, V.; Zecchin, M.; Fabbricatore, D.; Perri, F. A Neogene-Quaternary Geotraverse within the northern Calabrian Arc from the foreland peri-Ionian margin to the backarc Tyrrhenian margin. In Proceedings of the $86^{\circ}$ Congresso Nazionale della Società Geologica Italiana, Cosenza, Italy, 18-20 September 2012.

36. Cello, G.; Lentini, F.; Tortorici, L. La struttura del settore calabro-lucano e suo significato nel quadro dell'evoluzione tettonica del sistema a thrust sudappenninico. St. Geol. Camerti Vol. Spec. 1990, 27-34. Available online: http://193.204.8.201:8080/jspui/ handle/1336/216 (accessed on 21 August 2021).

37. Ortolani, F. Alcune considerazioni sulle fasi tettoniche mioceniche e pliocenche dell'Appennino meridionale. Boll. Soc. Geol. Ital. 1978, 97, 609-616.

38. Kastens, K.; Mascle, J.; Auroux, C.; Bonatti, E.; Broglia, C.; Channell, J.; Curzi, P.; Emeis, K.; Glacon, C.; Hasegawa, S.; et al. ODP Leg 107 in the Tyrrhenian Sea: Insights into passive margin and back-arc basin evolution. Geol. Soc. Am. Bull. 1988, 100, 1140-1156. [CrossRef]

39. Van Dijk, J.P.; Bello, M.; Brancaleoni, G.P.; Cantarella, G.; Costa, V.; Frixa, A.; Golfetto, F.; Merlini, S.; Riva, M.; Torricelli, S.; et al. A regional structural model for the northern sector of the Calabrian Arc (southern Italy). Tectonophysics 2000, 324, 267-320. [CrossRef]

40. Tansi, C.; Muto, F.; Critelli, S.; Iovine, G. Neogene-Quaternary strike-slip tectonics in the central Calabrian Arc (southern Italy). J. Geodyn. 2007, 43, 393-441. [CrossRef]

41. Critelli, S.; Muto, F.; Perri, F.; Tripodi, V. Interpreting provenance relations from sandstone detrital modes, southern Italy foreland region: Stratigraphic record of the Miocene tectonic evolution. Mar. Petrol. Geol. 2017, 87, 47-59. [CrossRef]

42. Tripodi, V.; Muto, F.; Brutto, F.; Perri, F.; Critelli, S. Neogene-Quaternary evolution of the forearc and backarc regions between the Serre and Aspromonte Massifs, Calabria (southern Italy). Mar. Petrol. Geol. 2018, 95, 328-343. [CrossRef]

43. Sartori, R. The main results of ODP Leg 107 in the frame of Neogene to Recent geology of Perityrrhenian areas. Proc. Ocean Drill. Program Sci. Results 1990, 107, 715-730.

44. Patacca, E.; Sartori, R.; Scandone, P. Tyrrhenian Basin and Apenninic Arcs: Kinematic relations since late Tortonian times. Mem. Soc. Geol. Ital. 1990, 45, 425-451.

45. Faccenna, C.; Mattei, M.; Funiciello, R.; Jolivet, L. Styles of back-arc extension in the Central Mediterranean. Terra Nova 1997, 9 , 126-130. [CrossRef]

46. Jolivet, L.; Faccenna, C.; Goffa', B.; Mattei, M.; Rossetti, F.; Brunet, C.; Storti, F.; Funiciello, R.; Cadet, J.P.; D'agostino, N.; et al. Midcrustal shear zones in postorogenic extension: The northern Tyrrhenian Sea case. J. Geophys. Res. 1998, 103, 12111-12586. [CrossRef]

47. Cavinato, G.P.; De Celles, P.G. Extensional basins in the tectonically bimodal central Apennines fold-thrust belt, Italy: Response to corner flow above a subducting slab in retrograde motion. Geology 1999, 27, 955-958. [CrossRef]

48. Cipollari, P.; Cosentino, D.; Gliozzi, E. Extension- and compression-related basins in central Italy during the Messinian Lago-Mare event. Tectonophysics 1999, 315, 163-185. [CrossRef]

49. Sorriso-Valvo, M.; Sylvester, A. The relationship between geology and landforms along a coastal mountain front, Northern Calabria, Italy. Earth Surf. Proc. Land. 1993, 18, 257-273. [CrossRef]

50. Monaco, C.; Tortorici, L. Tettonica estensionale quaternaria nell'Arco Calabro e in Sicilia orientale. St. Geol. Camerti. Spec. 1995, 2, 351-362.

51. Colella, A. Sedimentation, deformational events, and eustacy in the peri-Tyrrhenian Amantea Basin: Preliminary synthesis. G. Geol. 1995, 57, 179-193.

52. Ingersoll, R.V.; Bullard, T.F.; Ford, R.L.; Grimm, J.P.; Pickle, J.D.; Sares, S.W. The effect of grain size on detrital modes: A test of the Gazzi-Dickinson point-counting method. J. Sediment. Petrol. 1984, 54, 103-116.

53. Zuffa, G.G. Optical analyses of arenites: Influence of methodology on compositional results. In Provenance of Arenites; NATO ASI Series, 148; Zuffa, G.G., Ed.; D. Reidel Publishing Company: Dordrecht, The Netherlands, 1985; pp. 165-189.

54. Gazzi, P. Le arenarie del flysch sopracretaceo dell'Appennino modenese: Correlazioni con il flysch di Monghidoro. Mineral. Petrogr. Acta 1966, 12, 69-97.

55. Dickinson, W.R. Interpreting detrital modes of graywacke and arkose. J. Sediment. Petrol. 1970, 40, 695-707. 
56. Zuffa, G.G. Hybrid arenites: Their composition and classification. J. Sediment. Petrol. 1980, 50, 21-29.

57. Garzanti, E. Petrographic classification of sand and sandstone. Earth-Sci. Rev. 2019, 192, 545-563. [CrossRef]

58. Dickinson, W.R. Interpreting provenance relations from detrital modes of sandstones. In Provenance of Arenites; NATO ASI Series, 148; Zuffa, G.G., Ed.; D. Reidel Publishing Company: Dordrecht, The Netherlands, 1985; pp. 333-361.

59. Folk, R.L. Petrology of Sedimentary Rocks; Hemphill Publishing Company: Austin, TX, USA, 1968.

60. Ingersoll, R.V.; Suczek, C.A. Petrology and provenance of Neogene sand from Nicobar and Bengal fans, DSDP Sites 211 and 218. J. Sediment. Petrol. 1979, 49, 1217-1228.

61. Morrone, C.; De Rosa, R.; Le Pera, E.; Marsaglia, K.M. Provenance of volcaniclastic beach sand in a magmatic-arc setting: An example from Lipari island (Aeolian archipelago, Tyrrhenian Sea). Geol. Mag. 2017, 154, 804-828. [CrossRef]

62. Morrone, C.; Le Pera, E.; Marsaglia, K.M.; De Rosa, R. Compositional and textural study of modern beach sands in the active volcanic area of the campania region (southern italy). Sediment. Geol. 2020, 396, 105567. [CrossRef]

63. Marsaglia, K.M. Petrography and provenance of volcaniclastic sands recovered from the Izu-Bonin Arc, Leg 126: Proceedings of the Ocean Drilling Program. Sci. Results 1992, 126, 139-154.

64. Marsaglia, K.M. Basaltic island sand provenance. In Processes Controlling the Composition of Clastic Sediments: Geological Society of America; Special Paper; Johnsson, M.J., Basu, A., Eds.; Geological Society of America: Boulder, CO, USA, 1993; Volume 284, pp. 41-65.

65. Talling, P.J.; Masson, G.D.; Summer, E.J.; Malgesini, G. Subaqueous sediment density flows: Depositional processes and deposit types. Sedimentology 2012, 59, 1937-2003. [CrossRef]

66. Mutti, E.; Tinterri, R.; Remacha, E.; Mavilla, N.; Angella, S.; Fava, L. An Introduction to the Analysis of Ancient Turbidite Basins from an Outcrop Perspective. In AAPG Continuing Education Course Note 39; The American Association of Petroleum Geologists: Tulsa, OK, USA, 1999; pp. 1-98.

67. Dott, R.H. Wacke, graywacke and matrix-What approach to immature sandstone classification. J. Sediment. Petrol. 1964, 34, 625-632.

68. Heiken, G.; Wohletz, K.H. Volcanic Ash; University of California Press: Berkeley, CA, USA, 1985; Volume 245.

69. Garzanti, E.; Vezzoli, G. A classification of metamorphic grains in sands based on their composition and grade. J. Sediment. Res. 2003, 73, 830-837. [CrossRef]

70. Andò, S.; Garzanti, E.; Padoan, M.; Limonta, M. Corrosion of heavy minerals during weathering and diagenesis: A catalog for optical analysis. Sediment. Geol. 2012, 280, 165-178. [CrossRef]

71. Morton, A.C. Stability of detrital heavy minerals in Tertiary sandstones of the North Sea Basin. Clay Min. 1984, 19, 287-308. [CrossRef]

72. McBride, E.F. Diagenetic processes that affect provenance determinations in sandstone. In Provenance of Arenites; Zuffa, G.G., Ed.; D. Reidel Publishing Company: Dordrecht, The Netherlands, 1985; pp. 95-113.

73. Velbel, M.A. Surface textures and dissolution processes of heavy minerals in the sedimentary cycle: Examples from pyroxenes and amphiboles. In Heavy Minerals in Use; Developments in Sedimentology Series 58; Mange, M.A., Wright, D.T., Eds.; Elsevier: Amsterdam, The Netherlands, 2007; pp. 112-150.

74. Hall, A. Zeolitization of volcaniclastic sediments: The role of temperature and pH. J. Sed. Res. 1998, 68, 739-745. [CrossRef]

75. Boggs, S.; Seyedolali, A. Diagenetic albitization, zeolitization and replacement in Miocene sandstones, Sites 796,797, and 799, Japan Sea. Proc. Ocean Drill. Program Sci. Results 1992, 127, 131-151.

76. LeBas, M.J.; Lemaitre, R.W.; Streckeisen, A.; Zanettin, B. A chemical classification of volcanic rocks based on total alkali silica diagram. J. Petrol. 1986, 27, 745-750.

77. Shand, S.J. Eruptive Rocks; D. Van Nostrand Company: NewYork, NY, USA, 1927; Volume 360.

78. Lustrino, M.; Fedele, L.; Melluso, L.; Morra, V.; Ronga, F.; Geldmacher, J.; Duggen, S.; Samuele Agostini, S.; Cucciniello, C.; Franciosi, L.; et al. Origin and evolution of Cenozoic magmatism of Sardinia (Italy). A combined isotopic ( $\mathrm{Sr}-\mathrm{Nd}-\mathrm{Pb}-\mathrm{O}-\mathrm{Hf}-\mathrm{Os})$ and petrological view. Lithos 2013, 180, 138-158. [CrossRef]

79. Ronga, F. Petrogenesi delle vulcaniti del Sulcis (Sardegna Sud-occidentale). Ph.D. Thesis, University of Catania, Sicily, Italy, 2011.

80. Cas, R.A.F.; Wright, J.V. Volcanic Successions. Modern and Ancient. A Geological Approach to Processes, Products and Successions, 1st ed.; Cas, R.A.F., Wright, J.V., Eds.; Springer: Dordrecht, The Netherlands, 1996.

81. Palomares, M.; Arribas, J. Modern stream sands from compound crystalline sources: Composition and sand generation index. In Processes Controlling the Composition of Clastic Sediments; Lolmsson, M.L., Basu, A., Eds.; Geological Society of America: Boulder, CO, USA, 1993; Volume 284, pp. 313-322.

82. Heins, W.A.; Kairo, S. Predicting sand character with integrated genetic analysis. In Sedimentary Provenance and Petrogenesis: Perspectives from Petrography and Geochemistry; Arribas, J., Critelli, S., Johnsson, M.J., Eds.; Geological Society of America: Boulder, CO, USA, 2007; Volume 420, pp. 345-379.

83. Dickinson, W.R.; Suczek, C.A. Plate tectonics and sandstone composition. Am. Assoc. Petrol. Geol. Bull. 1979, 63, $2164-2172$.

84. Critelli, S.; Le Pera, E. Tectonic evolution of the Southern Apennines thrust-belt (Italy) as reflected in modal compositions of Cenozoic sandstone. J. Geol. 1995, 103, 95-105. [CrossRef]

85. Critelli, S.; Le Pera, E. Post-Oligocene sediment-dispersal systems and unroofing history of the Calabrian microplate, Italy. Int. Geol. Rev. 1998, 40, 609-637. [CrossRef] 